\title{
OPIEKA DUSZPASTERSKA WŚRÓD POLAKÓW WE FRANCJI W ŚWIETLE PROTOKOLU ZE ZJAZDU DUCHOWIEŃSTWA POLSKIEGO ODBYTEGO W CLAMART W 1938 ROKU
}

W okresie międzywojennym zarówno Kościół w Polsce, jak i władze rządowe zabiegały o zapewnienie rodzimej opieki religijnej wielomilionowej rzeszy wychodźstwa polskiego. Stwarzało to szeroką płaszczyznę współpracy, jakkolwiek nie wykluczało tarć i konfliktów. Motywacja współpracy miała różny charakter. Od czysto pragmatycznej i politycznej na poziomie Ministerstwa Spraw Zagranicznych - ambasady, konsulatów, do religijno-humanitarnej na poziomie miejscowych duszpasterzy polskich, którzy na co dzień stykali się z rozproszoną i najbardziej opuszczoną pod względem opieki konsularnej i religijnej częścią emigracji. Z chwilą objęcia 13 maja 1922 roku kierownictwa Polskiej Misji Katolickiej (PMK) przez ks. Wilhelma Szymbora ${ }^{1}$ zaistniały warunki dla rozwinięcia bardziej

Ks. dr hab. Józef SzYMAŃSKi, prof. AP - Instytut Historii i Politologii Akademii Pomorskiej w Słupsku; e-mail: jozef.szymanski@apsl.edu.pl

1 Wilhelm Szymbor - kapłan Zgromadzenia Księży Misjonarzy św. Wincentego a Paulo CM (lazarysta). Syn Antoniego i Teresy z d. Teller. Urodził się 16 października 1879 w Niwce k. Będzina. Studia filozoficzne i teologiczne odbył na Kleparzu i na Stradomiu. Święcenia kapłańskie przyjął 5 lipca 1903. W 1. 1903-1908 pracował w grupie rekolekcyjno-misyjnej, od 1908 był dyrektorem Małego Seminarium w Krakowie na Nowej Wsi; następnie wrócił na Kleparz do pracy w grupie misyjnej, w której był dyrektorem. Do pracy rekolekcyjno-misyjnej włączył wówczas (1912-1914) regularne wyjazdy (późna jesień i wczesna wiosna) do skupisk robotniczych emigrantów polskich na terenie Niemiec, Danii i Szwecji. W okresie I wojny światowej prowadził działalność organizacyjno-charytatywną jako członek Książęco-Biskupiego Komitetu Pomocy w Krakowie. W 1. 1919-1921 powrócił do pracy rekolekcyjno-misyjnej i równocześnie redagował „Roczniki Obydwóch Zgromadzeń św. Wincentego a Paulo". Na prośbę prymasa kard. Edmunda Dalbora 10 maja 1922 podjął się reorganizacji duszpasterstwa polonijnego we Francji. Zamieszkał w Paryżu, w domu generalnym Zgromadzenia i podjął urząd i obowiązki rektora Polskiej Misji Katolickiej we Francji. Prowadził ją do końca lipca 1928. Dokonał reorganizacji duszpasterstwa polonijnego, doprowadził do zjednoczenia różnych organizacji religijnych w Związek Polskich Towarzystw Katolickich. Pozostawił w czterech dekanatach: paryskim, północnym, wschodnim i zachodnim - 30 zorganizowanych placówek duszpasterstwa polskiego. Na początku lipca 1929, wraz z ks. Wiktorem Bieniaszem rozpoczął pracę rekolekcyjno-misyjną w ośrodkach duszpasterskich w Brazylii prowadzonych przez księży misjonarzy. Od sierpnia 1931 pełnił obowiązki superiora domu oraz rektora Instytutu Teologicznego 
planowanej współpracy PMK z Ambasadą Polską w Paryżu. Chodziło o to - by jak się wyraził ks. rektor - duszpasterze szli „ręka w rękę” z władzami polskimi. Na konieczność współpracy rządu, duszpasterzy, nauczycieli i przedstawicieli organizacji emigracyjnych 19 grudnia 1924 zwrócił również uwagę w swoim wystąpieniu na zjeździe księży polskich ambasador Alfred Chłapowski ${ }^{2}$, co w roku następnym skutkowało zawartym w tej sprawie porozumieniem ${ }^{3}$. Współpraca miała mieć charakter całkowicie apolityczny i powinna zmierzać do ulżenia doli emigrantów i do ich ochrony przed wynarodowieniem. Wszyscy zdawali sobie sprawę z roli i zaangażowania poszczególnych duszpasterzy stykających się na co dzień $\mathrm{w}$ terenie $\mathrm{z}$ życiem i problemami emigrantów, a tym samym rozumiejących ich lepiej, niż zajęci pracą biurową urzędnicy konsulatów.

Polska Misja Katolicka we Francji jurysdykcyjnie podlegała episkopatowi Francji, który ustanowił swojego delegata do duszpasterstwa migrantów. Z kolei biskupi ordynariusze ustanawiali delegatów diecezjalnych, którzy formalnie mianowali polskich duszpasterzy. Opiekunem duchowym polskiej emigracji był Prymas Polski, który w osobie kard. Augusta Hlonda, z ramienia Stolicy Apostolskiej od 1931 roku - nominacji Piusa XI, został „Protektorem” - Opiekunem polskiej emigracji w świecie. Dla łatwiejszej administracji posługą duszpasterską rektor PMK w 1923 roku w ramach rekolekcji kapłańskich rozpoczął duszpasterskie spotkania, ,zjazdy duchowieństwa polskiego”, wszystkich kapłanów Misji, które służyły wymianie doświadczeń duszpasterskich i dyskusji nad pojawiającymi się

w Krakowie na Stradomiu. W 1. 1933-1938 był po raz drugi redaktorem „Roczników Obydwóch Zgromadzeń św. Wincentego a Paulo”. 1 października 1935 został rektorem Śląskiego Seminarium Duchownego w Krakowie oraz superiorem domu Zgromadzenia. We wrześniu 1939 po likwidacji seminarium przez niemieckie władze okupacyjne, zamieszkał na Stradomiu, okazyjnie głosił rekolekcje parafialne oraz prowadził wykłady z teologii pastoralnej i homiletyki w konspiracyjnym seminarium księży salwatorianów w Krakowie na Zakrzówku. 11 sierpnia 1944 został aresztowany przez Niemców i więziony na Montelupich w Krakowie, a następnie w obozach koncentracyjnych: od 1 października 1944 we Flossenburgu, od 11 listopada w Mulsen, od 23 grudnia 1944 do 29 kwietnia 1945 w Dachau, nr obozowy 136986. Po wyzwoleniu z obozu zamieszkał w Paryżu i przez kilka miesięcy prowadził działalność duszpasterską w środowiskach polonijnych w rejonie Paryża. W 1946 powrócił do kraju i został superiorem domu oraz rektorem Instytutu Teologicznego na Stradomiu. Zmarł 9 grudnia 1946. Pochowany w grobowcu Zgromadzenia na cmentarzu Rakowickim w Krakowie. Archiwum Polskiej Misji Katolickiej we Francji. H. Historia duszpasterstwa polskiego we Francji. VII. Życiorysy i jubileusze rektorów Kościoła polskiego, Kościoła w Paryżu i PMK we Francji, 1. Szymbor Wilhelm; Misjonarze św. Wincentego a Paulo w Polsce (1651-2001), t. II-1: Biografie, red. tomu II J. Dukała CM, Kraków 2001, s. 484-490; Materiaty do dziejów Polskiej Misji Katolickiej we Francji, z. I: Księża polscy w duszpasterstwie okręgu paryskiego 1922-1929, oprac. O.B. Panek OC, Paris 1992, s. 111-113; H. Olszar, Śp. ks. Wilhelm Szymbor, „Wiadomości Archidiecezjalne Katowickie” 1993, nr 6, s. 312-317 (literatura i źródła); ks. J. SzYmaŃski, Duszpasterze Polonii i Polaków za granica. Stownik biograficzny, t. I, Lublin 2010, s. 142-144.

2 Ks. J. Szymański, Opieka duszpasterska nad Polakami we Francji do 1926 roku w ocenie ambasadora Alfreda Chłapowskiego, „Archiwa, Biblioteki i Muzea Kościelne” 100(2013), s. 389; M. WoŁos, Alfred Chtapowski (1874-1940). Biografia ambasadora Polski we Francji, Toruń 1999.

${ }^{3}$ R. Dzwonkowski, Polska opieka religijna we Francji 1909-1939, Poznań-Warszawa 1988, s. $235-282$. 
problemami emigracji polskiej ${ }^{4}$, dotyczącymi także współpracy z duszpasterzami francuskimi. Na pierwszym zjeździe ${ }^{5}$ powołano Radę Misji, a w 1924 roku dokonano podziału dotychczas zorganizowanych ośrodków duszpasterskich na 4 dekanaty.

W 1938 roku rekolekcje dla duszpasterzy polskich pracujących wśród wychodźstwa polskiego we Francji przeprowadził ks. Tomasz Mącior6, redaktor „Królowej Apostołów”. Odbywały się one w Clamart pod Paryżem ${ }^{7}$. W ćwiczeniach tych uczestniczyło 50 duszpasterzy z ówczesnym rektorem Polskiej Misji Katolickiej we Francji ks. Franciszkiem

${ }^{4}$ Archiwum Archidiecezjalne w Gnieźnie [dalej: AAG], Archiwum Prymasa Polski [dalej: APP], Akta Protektora Wychodźstwa Polskiego [dalej: APWP], Francja - PMK Varia, Dział III, Vol IV/16, Przyszłość Misji pod względem duszpasterskim. „Z punktu stawiam kwestię zupełnie jasno: Istnieją dwa kąty widzenia na emigrację polską we Francji, jeden francuski, drugi polski. Jakkolwiek weźmie się pod uwagę opinię francuską o emigracji, to zawsze i wszędzie przebija się jedna troska: zasymilowanie jak najwcześniejsze emigrantów i pewność, że ta asymilacja wcześniej czy później nastąpi. Z kimkolwiek ze strony polskiej mówi się o emigrantach polskich we Francji, znów jedna troska: zachowanie ich najdłużej dla narodowości polskiej i pewność, że emigranci polscy na zawsze zostaną Polakami”.

5 M. Brudzisz, Pierwsze zebranie księży Polskiej Misji Katolickiej we Francji, „Studia Polonijne" 33(2012).

6 Tomasz Mącior - kapłan Stowarzyszenia Apostolstwa Katolickiego SAC (pallotyn). Urodził się 16 grudnia 1897 w Szynwałdzie, k. Tarnowa. Syn Wojciecha i Salomei z d. Jop. Nauki gimnazjalne pobierał w Collegium Marianum w Wadowicach (1911-1917). Po uzyskaniu świadectwa dojrzałości, 8 października 1917 wstąpił do nowicjatu Stowarzyszenia. Studia filozoficzno-teologiczne odbył w Wadowicach (1918-1920) i w Rzymie (od października 1920-1924). Studia rzymskie uwieńczył doktoratami z filozofii na Angelicum i teologii na Gregorianum. Święcenia kapłańskie przyją 19 kwietnia 1924 w bazylice św. Jana na Lateranie z rąk abpa Polico. Po powrocie do Polski wykładał w pallotyńskim Seminarium Duchownym w Wadowicach, a następnie w Ołtarzewie i Sucharach (do 1934). W 1926 został rektorem pierwszego domu w Warszawie. Często wyjeżdżał na zastępstwa i prowadził rekolekcje oraz misje ludowe, w kraju i wśród polskich emigrantów we Francji. Był redaktorem „Przeglądu Katolickiego” (1929-1931), „Apostoła wśród Świata” (1934-1936) i „Królowej Apostołów” (1935-1939). W 1931 został wybrany sekretarzem generalnym, a 13 maja 1932 superiorem polskiej regii. 28 maja 1934 został pierwszym radcą regii i rektorem domu na Pradze (14 czerwca 1934). W końcu sierpnia 1936 został rektorem kościoła i domu pallotyńskiego w Nowosadach na Polesiu, a od 8 grudnia tegoż roku pierwszym proboszczem. Prowadził rekolekcje kapłańskie, w styczniu 1939 przeprowadził kurs Akcji Katolickiej dla polskich animatorów Stowarzyszeń Katolickich Młodzieży Męskiej w Amiens we Francji. W czasie wojny początkowo pod okupacją sowiecką a później niemiecką pozostał na swoim stanowisku. 29 czerwca 1942, został aresztowany przez Niemców i doprowadzony do więzienia w Baranowiczach, gdzie 13 lipca został rozstrzelany wraz z 15 kapłanami z dekanatu. Tam też został pochowany we wspólnej mogile na miejscowym cmentarzu prawosławnym. S. TyLus SAC, Leksykon polskich pallotynów 1915-2012, Ząbki-Poznań 2013, s. 361-365.

${ }^{7}$ Ks. T. MącIOR, Doroczny Zjazd Księży polskich we Francji, „Przegląd Katolicki” 4 XII 1938, nr 47 , s. $754-755$. 
Cegiełką ${ }^{8}$ i z ks. W. Staniszewskim ${ }^{9}$ z Londynu. Po rekolekcjach tradycyjnie odbyły się

${ }^{8}$ Franciszek CegielKa - kapłan Stowarzyszenia Apostolstwa Katolickiego SAC (pallotyn); czasowo kapłan Instytutu Ojców Szensztackich (1970-1974). Urodził się 16 marca 1908 w Grabowie n. Prosną. Syn Marcina i Marii z d. Nieszczęsna. Studia teologiczne odbył w 1. 1927-1931 w Uniwersytecie Gregoriańskim, uzyskując doktorat z teologii. Święcenia kapłańskie przyjął 4 kwietnia 1931 w Rzymie. W 1. 1931-1932 pracował w Polskiej Misji Katolickiej we Francji (Calvados, Seine Inferieure, La Manche). Po powrocie do Polski, pełnił obowiązki w pallotyńskim Małym Seminarium Duchownym w Chełmie na Pomorzu (1933-1934), a następnie w Wyższym Seminarium w Wadowicach na Kopcu (1935). Od grudnia 1936 zastępował w Paryżu przebywającego czasowo w Polsce ówczesnego rektora PMK ks. Witolda Paulusa. 18 czerwca 1937 został rektorem PMK we Francji. 26 października 1940 w Paryżu został aresztowany przez Niemców, i osadzony w hitlerowskich obozach koncentracyjnych. Po wyjściu z obozu w Dachau, od 24 maja 1945 kontynuował pracę w PMK we Francji. Z powodu presji władz komunistycznych PRL 18 września 1947 zrezygnował ze stanowiska rektora PMK we Francji i powrócił do Rzymu. 16 października 1948 opuścił Rzym i udał się do Stanów Zjednoczonych. W 1967 rozpoczął działalność naukową w kolegiach uniwersyteckich: Felician College w Lodi (1967-1971), Holy Family College w Filadelfii (1971-1976), a także w Caldwell College w stanie New Jersey (1971), oraz w Uniwersytecie Notre Dame w stanie Indiana (1973). Był dziekanem Wydziału Teologicznego. W 1970 w celu pogłębienia znajomości religii azjatyckich odbył podróże na Dalekim Wschodzie (Pakistan, Indie, Japonia, Tajlandia). W 1972 i 1974 został zaliczony do grupy wielkich wychowawców w Ameryce (Oustanding Educators of America). W 1977 został powołany na rektora domu w North Tonawanda i kustosza sanktuarium Infant Jesus Shrine. Odznaczony: przez prezydenta W. Raczkiewicza (1945 - Złotym Krzyżem Zasługi z Mieczami), od rządu francuskiego (1946 - Chevalier de la Légion d'Honneur i La Croix de Guère avec Palme), oraz najwyższym odznaczeniem Zakonu Maltańskiego (1961 - La Croix au Mérite de Premiere Classe). Zmarł 10 lutego 2003 w Buffalo. Archiwum Polskiej Misji Katolickiej we Francji. H. VII. Rektorzy PMK we Francji: życiorysy, jubileusze, życzenia, kondolencje: H. VII. 4. Cegiełka Franciszek; P. Personalia V. Akta osobisto duszpasterskie księży pracujących w ośrodkach duszpasterskich PMK we Francji, gromadzone po 1945, 26. Cegiełka Franciszek; P. VI. Ankieta personalna sporządzona w 1945 (-1955), 17. Cegiełka Franciszek; P. VIII. Akta Osobowe 1927-2000, 19. Cegiełka Franciszek; E. WeILer, Die Geistlichen in Dachau sowie in anderen Konzentrationslagern und in Gefängnissen, Mödling 1971, s. 165; R. DzwonkowsKi, Cegiełka Franciszek Antoni, w: Encyklopedia polskiej emigracji i Polonii, red. K. Dopierała, t. I: A-E, Toruń 2003, s. 301; S. TyLus, Leksykon polskich pallotynów 1915-2012, s. 91-99; F. GomuŁCZaK SAC, Cegietka. Pasterz Polonii, Ząbki 2014; J. SzYMański, Duszpasterze Polonii i Polaków za granica, t. I, s. 39-41.

${ }^{9}$ WladySEAw StaniszewSKI - kapłan archidiecezji poznańskiej. Urodził się w 1901 w Pleszewie. Syn Macieja i Marii z d. Magnuszewska. Po ukończeniu gimnazjum w Ostrowie Wielkopolskim rozpoczął studia filozoficzne w Gnieźnie. Studia teologiczne kontynuował w Poznaniu. 3 lipca 1927 z rąk bpa K. Radońskiego przyjął święcenia kapłańskie w Gnieźnie. W 1. 1927-1938 na Ostrowie Tumskim w Poznaniu pełnił obowiązki wikariusza, penitencjarza, ekonoma Seminarium Duchownego, kierownika biura Kancelarii Prymasa Polski. Ostatnim był urząd Dyrektora Biura w Kancelarii Prymasa Polski, który pełnił od 1931. W 1938 wyjechał do Anglii, gdzie objął stanowisko Rektora Polskiej Misji w Londynie. Założył pismo „Wiadomości Polskiej Misji Katolickiej w Londynie”. Na początku wojny opiekował się marynarzami, którzy jako pierwsi polscy żołnierze przybyli do Wielkiej Brytanii. W 1942 założył Dom Żołnierza Polskiego. Z jego inicjatywy bądź przy jego pomocy, powstały i rozwijały się na terenie Wielkiej Brytanii następujące instytucje: Katolicki Ośrodek Wydawniczy „Veritas”, „Gazeta Niedzielna” oraz tygodnik „Życie”. W czerwcu 1947 towarzyszy (jako przewodnik i tłumacz) kard. Bernardowi Griffinowi podczas wizyty w Polsce. Po utworzeniu 
obrady księży polskich, na które zaproszono także ambasadora Polski Juliusza Łukasiewicza, konsula generalnego w Paryżu Aleksandra Kawałkowskiego, dyrektora Katolickiej Agencji Prasowej ks. Zygmunta Kaczyńskiego ${ }^{10}$ i biskupa sufragana Paryża Emanuela Anatola Chaptala ${ }^{11}$.

w 1948 Polskiej Misji Katolickiej w Anglii i Walii, został jej pierwszym rektorem. W 1952 zainicjował powstanie Polish Benevolent Fund. Był przewodniczącym Rady Polskiej Macierzy Szkolnej, wiceprzewodniczącym Komisji Koordynacji przy Zjednoczeniu Polskim a także członkiem Komitetu Obywatelskiego Pomocy Uchodźcom Polskim. Popierał zakładanie i prowadzenie w ramach parafii sekcji charytatywnych. Oprócz zaangażowania w prace charytatywne był mecenasem polskiej kultury. Utworzył Dom Spokojnej Starości w Laxton Hall. Także dzięki jego poparciu w Londynie powstało osiedle św. Antoniego. We wrześniu 1974 przeszedł na emeryturę. Zamieszkał w Laxton Hall, gdzie zmarł 31 grudnia 1989. Prałat Jego Świątobliwości 1949; protonotariusz apostolski 1962; kanonik honorowy Kapituły Metropolitalnej Poznańskiej 1969. Odznaczony: Orderem Odrodzenia Polski (II), Medalem Lotniczym, Krzyżem Biskupa Polowego. Śp. ks. infułat Władysław Staniszewski, „Duszpasterz Polski Zagranicą” 41(1990), z. 2(175), s. 347-351; ks. A. RoMEJKo, Duszpasterstwo polonijne w Wielkiej Brytanii, Tuchów 2001, s. 300-301.

10 ZYGMUNT KACZYŃSKI - kapłan archidiecezji warszawskiej. Urodził się 15 października 1894 w Kaczyniu k. Łomży. Syn Franciszka i Józefy z d. Kopa. W 1. 1902-1910 uczęszczał do III gimnazjum w Warszawie. W 1910 rozpoczął naukę w Metropolitalnym Seminarium Duchownym w Warszawie. Od 1914 studiował w Akademii Duchownej w Sankt Petersburgu. Święcenia kapłańskie przyjął w 1917. W czasie I wojny światowej był działaczem organizacji charytatywnych i oświatowych na terenie Rosji i Finlandii. Po powstaniu polskich formacji wojskowych na Wschodzie pełnił w nich funkcję instruktora oświatowego. Po powrocie do Polski w 1917 został wybrany sekretarzem generalnym Stowarzyszenia Robotników Chrześcijańskich. W 1919 został wybrany posłem na Sejm Ustawodawczy z okręgu stołecznego. Był sekretarzem Prezydium Sejmu. Politycznie wchodził w skład klubu poselskiego Związku Ludowo-Narodowego, a następnie nowo powstałego Chrześcijańskiego Narodowego Klubu Robotników Chrześcijańskiej Demokracji. W maju 1920 współuczestniczył w tworzeniu partii chadeckiej, (Chrześcijańsko-Narodowego Stronnictwa Pracy). Jako kapelan brał udział w wojnie polsko-bolszewickiej. W 1922 ponownie został wybrany posłem. Działał w komisji budżetowej i regulaminowej; współtworzył projekty ustaw z zakresu prawa pracy. Do 1929 był członkiem najwyższych władz ChNSP (przekształconej w 1925 w Polskie Stronnictwo Chrześcijańskiej Demokracji). Był redaktorem pism „Pracownik Polski”, „Nowe Życie” i „Rzeczpospolita”. W 1922 został szambelanem papieskim i został odznaczony orderem Pro Ecclesia et Pontifice. W 1930 został powołany przez Konferencję Episkopatu Polski na dyrektora Katolickiej Agencji Prasowej. W 1935 został kanonikiem Kapituły Warszawskiej. Po wybuchu II wojny światowej w grudniu przedostał się na Węgry. Stamtąd w marcu wyjechał do Francji, gdzie jako przedstawiciel SP wszedł w skład Rady Narodowej. W rządzie gen. Władysława Sikorskiego został wiceministrem informacji i dokumentacji. Jednocześnie pełnił funkcję kapelana Prezydenta RP Władysława Raczkiewicza. W kwietniu 1943 po ogłoszeniu przez Niemców informacji o znalezieniu grobów polskich oficerów pod Katyniem zgłosił wniosek o zbadanie tej sprawy przez Międzynarodowy Czerwony Krzyż. W rządzie Stanisława Mikołajczyka został ministrem wyznań religijnych i oświecenia publicznego. We wrześniu 1945 powrócił do Polski. Zaangażował się w działalność odtwarzanego Stronnictwa Pracy. Od stycznia 1946 był proboszczem parafii Wszystkich Świętych w Warszawie. Przyczynił się do odbudowy zniszczonego w trakcie wojny kościoła. Brał udział w rozmowach ze stroną rządową dotyczących konkordatu, a po ich zerwaniu próbował pośredniczyć w kontaktach rządu z Watykanem. Od listopada 1945 był drugim redaktorem naczelnym „Tygodnika Warszawskiego”, organu Kurii Metropolitarnej Warszawskiej. Był kandydatem na stanowisko dyrektora mającej być 
Kopia dokumentu znajduje się w Archiwum Polskiej Misji Katolickiej we Francji. G. III. 2. Zjazdy duszpasterskie, sympozja, kursy dokształcające, 1923-1996; G. III. 2. 4. Zjazdy w Clamart: 1938.

Dokument oryginalny w formie maszynopisu, przechowywany jest w Archiwum Archidiecezjalnym w Gnieźnie, Archiwum Prymasa Polski, Akta Protektora Wychodźstwa Polskiego, Francja, Dział III/19, Protokół ze Zjazdu Duchowieństwa Polskiego odbytego po zakończeniu rekolekcji w Clamart pod Paryżem w dniu 25 listopada 1938 r., k. 10. [każda strona opatrzona okrągłą pieczęcią rektora Polskiej Misji Katolickiej we Francji i jego podpisem].

Protokół ze Zjazdu Duchowieństwa Polskiego odbytego po zakończeniu rekolekcji w Clamart pod Paryżem w dniu 25 listopada 1938 roku.

W dniu 25 XI po uroczystej Mszy św. odprawionej na intencję Księży Polskich przez J.E. ks. Biskupa Mesguen z Poitiers zebrali się wszyscy duszpasterze polscy wraz z ks. rektorem drem Cegiełką o godz. 9 na sali, gdzie po wspólnym odmówieniu modlitw do Ducha Św. rozpoczęto doroczny Zjazd.

Zjazd zagaił ks. rektor Cegiełka, powołując na sekretarza zjazdu ks. kanonika [Antoniego] Sawickiego ${ }^{12}$, jako stałego stenografa wszystkich Zjazdów, oraz do pomocy ks. dyr [Ludwika] Makulca ${ }^{13}$.

reaktywowanej Katolickiej Agencji Prasowej. Od 1947 działał w prymasowskim komitecie odbudowy 55 kościołów warszawskich. 31 sierpnia 1948 wraz z członkami komitetu redakcyjnego „Tygodnika Warszawskiego" został aresztowany przez UB, po tygodniu zwolniony, po podpisaniu zobowiązania do zachowania tajemnicy i regularnego meldowania się w Urzędzie Bezpieczeństwa Publicznego. 26 kwietnia 1951 ponownie został aresztowany pod zarzutem zamiaru zmiany przemocą ustroju ludowo-demokratycznego państwa polskiego. 29 sierpnia tego samego roku Wojskowy Sąd Rejonowy w Warszawie skazał go na 10 lat więzienia. 13 maja 1953 został zamordowany w więzieniu mokotowskim. W 1958 został uniewinniony i zrehabilitowany. Jego symboliczny grób znajduje się na Cmentarzu Wojskowym na Powązkach w Warszawie w Kwaterze „Na Łączce”. Był odznaczony m.in. Krzyżem Walecznych. Materiały do Dziejów Polskiej Misji Katolickiej we Francji, z. XVII: Księża polscy $w$ duszpasterstwie na terenie Francji południowej 1940-1945, oprac. B. Panek, Paryż 1992, s. 93-95; J. Myszor, Leksykon duchowieństwa represjonowanego w PRL w latach 1945-1989, Górna Grupa 2003.

${ }^{11}$ Ks. S. TyLus, Prace polskich Pallotynów wśród emigracji (do utworzenia francuskiej Regii Miłosierdzia Bożego - 2 VIII 1946), „Archiwa, Biblioteki i Muzea Kościelne” 66(1996), s. 473.

12 ANTONi Sawicki - kapłan archidiecezji krakowskiej. Urodził się 22 października 1901 w Osieczanach. Syn Jana i Katarzyny z d. Majda. Po uzyskaniu świadectwa dojrzałości w Gimnazjum w Myślenicach w 1921, podjął studia na Wydziale Teologicznym UJ. Święcenia kapłańskie z rak bpa A. Sapiehy przyjął 20 września 1924. Obowiązki duszpasterskie w charakterze wikariusza podjął latem następnego roku: był katechetą w Trzebini. We Francji przebywał od 1930, w 1931 pełnił posługę w Barlin. Od 1934 w Bruay-en-Artois. Od 1 sierpnia 1936 w Caen. Od 1939 w rezydował w Dechy; obsługiwał kolnie w: Dechy (145 rodzin), w każdą niedzielę i święto, Vuillemin (115 rodzin), w każdą 
Przystępując do powitania zebranych wygłasza ks. rektor następujące przemówienie.

Otwierając dzisiejszy Zjazd witam serdecznie wszystkich Czcigodnych Księży tutaj tak licznie zebranych. Jestem szczęśliwy, że mogę powitać wśród konfratrów drogiego gościa z kraju, Przewielebnego Księdza Prałata Kaczyńskiego, dyrektora K.A.P-owej. Księże prałacie. Wszyscy jesteśmy zadowoleni z Twego przyjazdu. Cieszymy się że mamy wśród siebie przedstawiciela prasy katolickiej, tym bardziej że w księdzu prałacie widzimy swojego przyjaciela, który nie zawahał się wziąć nas w obronę wtedy, gdy na łamach „Gazety Kościelnej” ukazywały się krzywdzące nas artykuły, pióra ks. Juliana Unszlichta ${ }^{14}$, obcego nam pochodzeniem. Za tę obronę składam dzisiaj księdzu prałatowi

niedzielę i święto, Auberchicourt (68 rodzin), w co drugą niedzielę, Monchecourt (63 rodziny), co drugi miesiąc w piątą niedzielę. Na terenie istniały jeszcze inne kolonie: Sin le Noble (78 rodzin) i Guesnain (72 rodziny). Podczas II wojny światowej zgłosił się jako ochotnik do Armii Polskiej (kapelan I Wileńskiego Pułku Artylerii Lekkiej). Brał udział w lądowaniu w Normandii i walkach na terenie Francji. Od 1948 był proboszczem w Dechy. 1 października 1956 został dziekanem dla diecezji Cabmrai i Lille. Posługę duszpasterską pełnił w: Beaucaire, Coetquidan, Colombelles, Dives-sur-Mer, Divion, Ecaillon, Grenoble, Haillicourt Hersin-Coupigny, Houdain, Le Havre-Graville, Marseille, Monchecourt, Mondeville, Paris, Potigny, Sin-Le-Noble, Vuillenin. Archiwum Polskiej Misji Katolickiej we Francji. P. II. „Kwestionariusz” prezentujący stan z 20 stycznia 1949. 63. Sawicki Antoni; P. IV. Ankieta personalna księży pracujących w ośrodkach duszpasterskich PMK w 1943: [52 odpowiedzi] 229. Sawicki Antoni; P. VII. Kwestionariusze osobowe ze zdjęciami [1959] 26. Sawicki Antoni; A. KAPUŚNIAK, ks. J. SzCZEPANIAK, Katalog alumnów krakowskiego seminarium duchownego (1901-1938), Kraków 2006, s. 211; Materiaty, z. XVII, s. 164-166.

${ }^{13}$ LudwIK MAKULEC - kapłan diecezji łomżyńskiej. Urodził się 25 sierpnia 1907 w Garwolinie. Syn Antoniego i Agnieszki z d. Piesiewicz. Po uzyskaniu w 1925 świadectwa dojrzałości w Gimnazjum im. Piotra Skargii w Łomży, podjął studia filozoficzno-teologiczne w Wyższym Seminarium Duchwnym w Łomży. Święcenia kapłańskie przyjął 15 marca 1930. Obowiązki duszpasterskie w charakterze wikariusza podjął: (od 1 kwietnia w Zuzeli, od 1 marca 1931 w Zarębach Kościelnych. W tymże samym roku podjął obowiązki duszpasterskie wśród wychodźstwa polskiego we Francji. Posługą duszpasterską obejmował kolonie polskie w: Auby, Baudras, Caen, Clamart, Colombelles, Courcelles, Dives-Sur-Mer, Dorignies, Flers, Giberville, Gouvix, Langannerie, Leforest, Lens, Lisieux, Mondeville, Paris, Pont-de-la-Deule, Potigny, Roost-Warendin, St-Germain-Le-Vasson, Valenciennes, Waziers. Był dziekanem okręgu paryskiego. Podczas okupacji we Francji zaangażowany był w polskiej organizacji wojskowej. W 1946 udał się do Stanów Zjednoczonych i podjął posługę duszpasterską w parafii św. Stanisława w Nowym Jorku. W 1972 przeszedł na emeryturę i zamieszkał w Phoenix Arizona, gdzie zmarł 15 października 1982. Pochowany został na cmentarzu diecezjalnym św. Franciszka w Phoenix. Odznaczony został Złotym Krzyżem Zasługi, i medalem „Resistance”. Archiwum Polskiej Misji Katolickiej we Francji. F. Duszpasterstwo - jego organizacja i życie religijne wiernych w polskojęzycznych ośrodkach duszpasterskich, 1926-1993. F. IV. Praca duszpasterska kapłanów Misji we Francji okupowanej przez Niemców pod kierownictwem ks. Cz. Wędziocha, [p. o.] Rektora Misji, w 1. 1940-1944/1945. F. IV. 1. Duszpasterze: 22. Makulec Ludwik; P. Personalia V. Akta osobisto duszpasterskie księży pracujących w ośrodkach duszpasterskich PMK we Francji, gromadzone po 1945. 146. Makulec Ludwik; ks. W. Jemielity, Śp. Ks. Ludwik Makulec, „Rozporządzenia Urzędowe Łomżyńskiej Kurii Diecezjalnej" 4(1982), s. 89-90; ks. W. GuZEwicz, Duchowieństwo diecezji łomżyńskiej w II Rzeczypospolitej, Lublin 2003, s. 79, 97, 131, 140, 172, 257.

14 Julian UnsZlicht - kapłan diecezji Meaux. Urodzony w rodzinie żydowskiej 10 stycznia 1883 w Mławie. Syn Henryka i Michaliny z d. Luxemburg. Od 1885 wychowywał się w Warsza- 
w imieniu Duchowieństwa polskiego we Francji serdeczne podziękowania. Tą przysługą zdobył sobie ksiądz prałat serdeczną wdzięczność całego duchowieństwa. (oklaski) Prosimy księdza prałata, żeby był łaskaw żywić nadal przyjacielskie i serdeczne uczucia wobec nas.

wie, uczęszczał do szkoły polskiej Pankiewicza-Trojanowskiego, następnie kontynuował studia $\mathrm{z}$ architektury $\mathrm{w}$ szkole politechnicznej. Na skutek zaangażowania się $\mathrm{w}$ ruchu rewolucyjnym, w ramach SDKPiL w lutym 1904 został zatrzymany i uwięziony w Cytadeli. Zwolniony za kaucją, zbiegł „,za granicę” do Galicji, gdzie podjął studia z filozofii na UJ. W 1. 1904-1905 był sekretarzem SDKPiL, w sekcji młodzieżowej, wydawał dziennik „Czerwony Sztandar”. We wrześniu 1905 został oddelegowany do Paryża celem zorganizowania sekcji SDKPiL w stolicy Francji. W grudniu 1905 wysłany do Warszawy został ponownie aresztowany. Po wyjściu z więzienia wrócił do Francji i na Wydziale Nauk Ścisłych w 1910 otrzymał licencjat z prawa. Uczestnicząc w ruchu rewolucyjnym nie podzielał antypolonizmu żydowskich rewolucjonistów, wystąpił z SDKPiL i w 1909 wstąpił do PPS Piłsudskiego. Pod pseudonimem Esdecki, w „Przedświcie” pisał artykuły zwalczające antypolonizm żydowski. Walka Żydów rewolucjonistów z nim zbliżyła go bardziej do Polaków, i mimo wyznawanego indyferentyzmu i darwinizmu zainteresował się religią własnego narodu, osobą Chrystusa. Studium literatury w tym zakresie w maju 1912 doprowadziło go do chrztu św. W czasie I wojny światowej służył w wojsku francuskim. W 1915 dostał się do niewoli niemieckiej, gdzie podjął myśl o wstąpieniu do seminarium duchownego. W październiku 1920 rozpoczął studia w Seminarium Duchownym dla Spóźnionych Powołań w Meaux. Tamże, 13 lipca 1924 z rąk bpa Ludwika Gaillarda przyjął święcenia kapłańskie. Początkowo był profesorem w seminarium dla spóźnionych powołań St. Jean. Od 1925, zamieszkując w Changis St. Jean, podjął posługę duszpasterską wśród wychodźstwa polskiego, szczególnie rozproszonego na skutek zatrudnienia w rolnictwie. Pełnił posługę duszpasterską w: Abbaye de Cendras, Barcy, Champcenest, Changis-Saint-Jean, Chenoise, Charmy, La Ferte-sous-Jouarre, Longueville, Marcylly, Meaux, Melun, Messy, Paris, Prowins, St-Cyran du Jambot, Villegruis, Villenauxe et Willuis, aż do wejścia wojsk niemieckich w 1940. Po agresji Niemiec na Francję, przeniósł się do Francji nieokupowanej, gdzie najpierw przebywał w Fontgombaud, a następnie był kapelanem Sióstr św. Urszuli w Saint Cyran du Jambot. [Jego matka i siostra zostały rozstrzelane przez Niemców w Warszawie w 1944; trzech braci zginęło w walkach powstańczych]. Po zakończeniu działań wojennych za zgodą bpa diecezji Meaux, ze względu na stan zdrowia pozostał kapelanem u sióstr. Nadal pracował dla Polaków. Za zasługi dla Polaków został odznaczony Krzyżem Niepodległości, a za zasługi dla Francji Krzyżem Kombatanta Wolontariusza. W lipcu 1953 udał się do Tours, aby przygotować kolejną misję dla Polaków. Tam zmarł 30 lipca 1953 w Domu Sióstr Urszulanek. Archiwum Polskiej Misji Katolickiej we Francji. F. VIII. 9. Objazdy kolonii polskich w latach 1927-1930, 1933-1934, 1940, 1955; G. Duszpasterze Misji - kapelani. G. VII. Wykazy ośrodków duszpasterskich, duszpasterzy, wspólnot zakonnych i statystyki PMK we Francji, 1929-1992. G. VII. 1. Katalogi drukowane (schematyzmy) „Duszpasterstwa Polskiego we Francji” (oraz duchowieństwa): G. VII. 1. 1. Druki 1937/1938; 1939-1961: Duszpasterstwo Polskie we Francji (stan z dnia 1 marca 1940); J. Misje - ośrodki duszpasterskie. I. Dekanat Paryski. 8. 3, Meaux 1929-1947; Materiaty, z. XVIII, s. 93; J.-B. Molin, L' abbe Julien Unszlicht, pretre du Dioces de Meaux (1883-1953), „Revue d'Histoire et d' Art de la Brie et du Pays de Meaux” 38(1987), s. 89-107; P. BADURA SJ, Unszlicht Julian (1883-?), w: Stownik polskich teologów katolickich 1918-1981, red. ks. L. Grzebień SJ, t. VII, Warszawa 1983, s. 343-344; J. Unszlicht, Duszpasterstwo Wychodźców w Francji, „Ateneum Kapłańskie” 35(1935), s. 170-175; K. Smoroński, Przedmowa, w: J. Unszlicht, Życie i nauka Jezusa Chrystusa w zarysie, Tuchów 1934, s. 5-6, biogram Unszlichta; M. l' abbe Julien Unszlicht, „La Semaine Religieuse du Dioces de Meaux” 84(1953), s. 291; R. DzwonkowSKI, Polska opieka religijna we Francji, s. 121, 140, 144, 174, 251-254, 259, 276-277, 285-287, 301. 
Witam z kolei serdecznie naszego Czcigodnego ks. dra [Augustyna] Jakubisiaka ${ }^{15}$. Ksiądz profesor zdobył serca i dusze kapłanów polskich we Francji. W ubiegłym roku powiedziałem, że uważamy go za filozofa tut. kleru polskiego a dzisiaj niech nam będzie wolno nazywać teologiem polskim we Francji, który głęboko wnika w potrzeby duszy chorej, ukazując jej Boga - Miłość Nieskończoną. Ksiądz profesor rzuca nam zapracowanym $w$ trudach pracy duszpasterskiej, promienie światła, przypomina nam serdeczne prawdy naszej wiary i za to jesteśmy Mu wdzięczni. (oklaski)

Witam bardzo serdecznie wszystkich Księży Dziekanów. Wyrażam radość z powodu odznaczeń dwóch członków korpusu dziekańskiego. Złote Krzyże Zasługi otrzymali: ks. dziekan [Wojciech] Rogaczewski ${ }^{16}$ i ks. [Wacław] [Tomasz] Knapik ${ }^{17}$. Równocześnie

${ }^{15}$ AUGUSTYN JAKUBISIAK - kapłan archidiecezji warszawskiej. Urodził się 28 maja 1884 w Warszawie. Syn Antoniego i Julii z d. Dybkowska. Po ukończeniu gimnazjum w Warszawie, podjął studia filozoficzno-teologiczne w Metropolitalnym Wyższym Seminarium Duchownym, gdzie w 1906 przyjął święcenia kapłańskie. Przez cztery lata był wikariuszem. Od 1910 studiował na Uniwersytecie Katolickim i na Sorbonie w Paryżu. W 1912 uzyskał doktorat. Od 1915 władze francuskie powierzyły mu funkcję kapelana wszystkich jeńców-Polaków (17 tys.) we Francji. Wydawał dla nich pismo „Jeniec Polski”. Następnie został kapelanem w armii J. Hallera i razem z armią przybył do Polski. W Warszawie pełnił obowiązki kapelana Francuskiej Misji Wojskowej. W 1920 powrócił do Paryża i podjął obowiązki duszpasterskie. Od 1926 był kapelanem więźniów Polaków w więzieniach departamentu Sekwany. Jednocześnie prowadził badania naukowe z zakresu filozofii. Z chwilą wyzwolenia Francji, w 1944 powrócił do Paryża i został delegatem Ministerstwa Wyznań Religijnych i Oświecenia Publicznego emigracyjnego rządu londyńskiego. Zmarł 23 listopada 1945 w Paryżu. Pochowany na cmentarzu Montmorency. Odznaczony został: Złotym Krzyżem Zasługi i Komandorią Orderu Polonia Restituta. I. DĄBSKA, Jakubisiak Augustyn, w: Polski Stownik Biograficzny, t. X, Wrocław-Warszawa-Kraków 1962-1964, s. 374-375; Materiaty, z. I, s. 37-38; S. JANECZEK, Jakubisiak Augustyn, filozof, teolog, duszpasterz, w: Encyklopedia Katolicka, t. VII, kol. 734-738 bibliogr.; P.J. BADURA, Jakubisiak Augustyn (1884-1945), w: Stownik polskich teologów katolickich, t. V, s. 563-564.

16 Wojciech RogaczewSKI - kapłan diecezji warmińskiej, od 1927 diecezji chełmińskiej. Urodził się 23 kwietnia 1888 w Dąbrówce k. Sztumu. Syn Jana Michała i Anny z d. Hoffman. W 1. 1900-1910 był uczniem gimnazjum brodnickiego, tam od 1908 był prezesem tajnego Kółka Filomatów. W 1910 podjął studia weterynaryjne w Berlinie, a następnie w 1. 1911-1914 podjął studia filozoficzno-teologiczne w braniewskim seminarium duchownym. Po przyjęciu święceń kapłańskich 4 lipca 1914 został wikariuszem w parafii św. Katarzyny w Kętrzynie, gdzie m.in. opiekował się polskimi robotnikami sezonowymi i jeńcami wojennymi, Polakami z armii carskiej. Angażował się w ożywienie polskiego ruchu narodowego, przy parafii w Kętrzynie i sąsiednich miejscowościach. $\mathrm{Z}$ tego powodu został aresztowany na początku 1919. Z aresztu został zwolniony dzięki interwencji bpa Augustyna Bludau i przeniesiony na samodzielną placówkę do Prawdzisk k. Ełku, gdzie działał na rzecz rozbudzenia polskości, wbrew zakazom wprowadził nauczanie religii w języku polskim. W czasie plebiscytu współdziałał z Naczelną Radą Ludową w Poznaniu oraz z Komitetem Plebiscytowym w Grajewie. W 1926 został wydalony z terenu Prus Wschodnich i czasowo przebywał na terenie diecezji chełmińskiej. Na życzenie kard. A. Hlonda wyjechał do Francji. Od 28 stycznia 1927 podjął posługę duszpasterską w Briey, a od $1930 \mathrm{w}$ Metzu jako dziekan na wschodnią Francję. Po wydaleniu przez Niemców w sierpniu 1940 z Metzu, przeniósł się do Lyonu, gdzie kierował Centralą Duszpasterstwa Polskiego w południowej Francji. Uczestniczył we francuskim ruchu oporu. Posługą duszpasterską obejmował rodaków w: Auboue, Blenod Le Pont-A-Mousson, Bouligny, Briey, Clairevaux, Clamart, Foug, Giraumont, Hayange, Herserange, Homecourt, Houlaine, Hussigny, Jarny, Joudreville, Longlavitlle, Lourdes, Ludres, Luneville, Lyon, Mancieulles, 
powiadamiam, że wśród dziekanów polskich mamy dwie nowe siły. Ks. Sawickiego odzna-

Maxeville, Metz, Mont-Bonvillers, Montiers, Mont-Saint-Martin, Mouriere, Nancy, Paris, Petite-Rosselle, Piennes, Pompey, Pont-a-Mousson, Rehon, Roubaix, Saint Maur, Saint-Ludan, Saulnes, Stiring-Wendel, Strasbourg, Toul, Trieux, Tucquegnteux, Valleroy, Varangeville, Villerupt. 8 maja 1943 w Lyonie był aresztowany przez Niemców, w tym samym dniu podczas próby ucieczki został ciężko ranny. Więziony był w Mont-Luc i obozach przejściowych w Fresnes i Compiègne, a od 29 stycznia 1944 w obozie koncentracyjnym w Buchenwaldzie, gdzie zmarł na tyfus 16 marca 1944. Został odznaczony przez polskie władze państwowe jeszcze przed 1939 - Złotym Krzyżem Zasługi. Tablica upamiętniająca zasługi ks. Wojciecha Rogaczewskiego znajduje się w kościele katolickim w Metzu, a także w kościele św. Katarzyny w Kętrzynie. Szkoła Podstawowa w Prawdziskach nosi Jego imię. Archiwum Polskiej Misji Katolickiej we Francji. E. IV. 15. 1. Stowarzyszenie Dzieci Polskich we Francji; projekty: księdza W. Rogaczewskiego 10. 05. 1932; F. VIII. 1. Duszpasterstwo „objazdowe”, 1927-1952; dok. z 27 XI 1933: Podział departamentów wśród duszpasterzy polskich, objeżdżających robotników, zwłaszcza rolnych (13 rejonów), Zakładka 1. 2: Korespondencja, zaangażowania i relacje z pracy duszpasterskiej w 1928, ks. rektora Szymbora i licznych polskich duszpasterzy: Rogaczewski; G. IX. 3. Wykaz niektórych odznaczonych Złotym Krzyżem Zasługi z Mieczami: ks. Wojciech Rogaczewski; P. IV. Ankieta personalna księży pracujących w ośrodkach duszpasterskich PMK w 1943: 223. ks. Wojciech Rogaczewski; P. VIII. 4: 102-125. Akta Osobowe 1927-2000: 113. ks. Wojciech Rogaczewski; R. II. 7. Korespondencja Rektora i sekretarza w sprawach PMK, 1927-1939, R. II. 7. 1. Rok 1927, I -V; ks. H. Mross, Słownik biograficzny kapłanów diecezji chetmińskiej wyświęconych w latach 1821-1920, Pelplin 1995, s. 271; ks. W. TomKIEwICZ, Życie księdza Wojciecha Rogaczewskiego, w: 175-lecie Polskiej Misji Katolickiej we Francji. Akta kolokwiów, t. I, red. G. Garçon i in., Nowy Sącz 2013, s. 148-157.

${ }^{17}$ WaCŁaW T. KNAPIK - kapłan Zgromadzenia Księży Misjonarzy św. Wincentego a Paulo CM (lazarysta). Urodził się 3 marca 1897 w Piekarach Śląskich. Syn Karola i Joanny z d. Sikora. Do szkoły podstawowej uczęszczał w miejscowości urodzenia, gdzie językiem wykładowym był język niemiecki. Następnie, w 1. 1911-1914 uczył się w szkole polskiej, w Małym Seminarium Księży Misjonarzy na Nowej Wsi. 25 listopada 1915 wstąpił do Zgromadzenia Księży Misjonarzy w Krakowie. Świadectwo dojrzałości uzyskał 12 czerwca 1919. Studia filozoficzno-teologiczne ukończył w Instytucie Teologicznym Księży Misjonarzy w Krakowie na Stradomiu. 29 czerwca 1922 z rąk ks. bpa Adama Stefana Sapiehy przyjął święcenia kapłańskie w Katedrze Wawelskiej. Od listopada tegoż roku kontynuował studia teologiczne we Francji i pełnił posługę duszpasterską w Oignies. 9 listopada 1923 w Strasburgu uzyskał licencjat z teologii i rozpoczął studia doktoranckie. W 1. 19251928 w Paryżu pełnił funkcję Sekretarza Generalnego Misji Polskiej. Od 1928 do 1937 udzielał się jako misjonarz objazdowy. Zamieszkiwał w tym czasie w Lyonie i stamtąd dojeżdżał do ośrodków duszpasterskich w: Roche la Moliere i Firminy. W 1. 1938 -1952 przebywał w Beaulieu i obsługiwał trzy parafie polskie, odległe od siebie o $4-5 \mathrm{~km}$. W czasie okupacji współpracował z Francuskim Ruchem Oporu. Od 1952 pełnił funkcję superiora domu Polskiej Prowincji Zgromadzenia Misji we Francji w Courbevoie. W 1955 został asystentem generalnym Kurii Generalnej Zgromadzenia w Paryżu. Urząd ten pełnił do 1963. W ostatnim roku po przeniesieniu Kurii Generalnej do Rzymu, pracował w Wiecznym Mieście. W 1963 powrócił do kraju i zamieszkał w Krakowie na Stradomiu. Nauczał języka francuskiego w Instytucie Teologicznym Księży Misjonarzy oraz był spowiednikiem kleryków i Sióstr Miłosierdzia. Odznaczony został: Krzyżem Komandorskim Orderu Odrodzenia Polski 3 klasy, Srebrnym Krzyżem Zasługi R.P. (1937), Brązowym Krzyżem Zasługi z mieczami (1944), Médaille de la Résistance Française (1966) i Srebrnym Krzyżem Zasługi Polskiej Misji Katolickiej we Francji (1947). Zmarł 4 kwietnia 1980 w Krakowie. Materiaty, z. I, s. 46-48; Srebrne gody kapłańskie księdza dziekana Knapika, „Polska Wierna” 6 VII 1947; ks. W. UMiŃsKi CM, Polska 
czonego godnością kanonika i ks. [Antoniego] Szewczyka ${ }^{18}$, który sprawuje kierownictwo Związku Bractw Różańcowych we Francji. Witam bardzo serdecznie wszystkich Księży, a zwłaszcza tych, którzy w tym roku na nasz teren przybyli. A więc ks. dra [Czesława] Wędziocha ${ }^{19}$, który nie tylko spełnia pracę duszpasterską w Amiens, ale zamienia się

prowincja Zgromadzenia Księży Misjonarzy w latach 1918-1939, Kraków 2009, s. 279; M. BRUDZISZ, Pierwsze zebranie księży Polskiej Misji Katolickiej we Francji, s. 146; R. Dzwonkowski SAC, Przemiany polskiej parafii w pótnocnej Francji (1922-1972). Studium historyczno-socjologiczne parafii w Oignies, „Studia Polonijne” 1(1976), s. 47.

${ }^{18}$ Antoni SzEWCZYK - kapłan diecezji sandomierskiej. Urodził się 30 marca 1897 w Borku k. Kozienic. Syn Wincentego i Ewy z d. Drążyk. Święcenia kapłańskie przyjął 21 maja 1921. Podjął obowiązki duszpasterskie jako wikariusz w Ciepielowie, od 1922 w Szewnie i od 1926 w Miedzerzy. 21 sierpnia 1927 podjął posługę duszpasterską w La Ricamarie. Następnie pracował w: Barlin, Billy-Montigny, Bruay-en-Artois, Calonne-Ricouart, Divion, Haillicourt, Haudain, Hersin-Coupigny, Kremlin-Bicetre, Lens, Noeux-les-Mines, Ostricourt, Paris, Rouvroy, Saint-Etienne-Le-Soleil, Sallaumines, Valencienes. W 1949 został proboszczem w Lipsku nad Wisłą. Później był proboszczem w Ostrowcu Świętokrzyskim i dziekanem do 1964. W 1965 osiadł w Domu Księży Emerytów w Sandomierzu. Zmarł 16 sierpnia 1986 w Sandomierzu. Archiwum Polskiej Misji Katolickiej we Francji. F. IV. Praca duszpasterska kapłanów Misji we Francji okupowanej przez Niemców pod kierownictwem ks. Cz. Wędziocha, [p. o.] Rektora Misji, w 1. 1940-1944/1945. F. IV. 1. Duszpasterze: 38). Szewczyk Antoni, dziekan w Barlin, po porozumieniu z prymasem, od 1 września 1943 jako dziekan będzie urzędował w Bruay-en-Artois; P. Personalia. IV. Ankieta personalna księży pracujących w PMK, 1943, 40. Szewczyk Antoni; R. II. 7. Korespondencja Rektora i sekretarza w sprawach PMK, 1927-1939, R. II. 7. 1. Rok 1927, I-V. Materiaty do dziejów Polskiej Misji Katolickiej we Francji, z. II: Księża polscy w duszpasterstwie poludniowej Francji 1922-1929, oprac. O.B. Panek OC, Paris 1992, s. 96-99.

${ }^{19}$ CzesŁaw WęDzıoch - kapłan Stowarzyszenia Apostolstwa Katolickiego SAC (pallotyn). Urodził się 5 lipca 1906 w Grabowie nad Prosną. Syn Wojciecha i Marii z d. Rybczyńska. Po ukończeniu szkoły powszechnej w Grabowie, po krótkim uczęszczaniu do państwowego gimnazjum w Nakle, w 1924 wstąpił do Collegium Marianum w Wadowicach. Następnie do nowicjatu na Kopcu. Studia filozoficzne rozpoczął w Wadowicach i po roku kontynuował w Sucharach, a studia teologiczne odbył w Rzymie na Uniwersytecie Gregoriańskim. Święcenia kapłańskie przyjął w Rzymie 20 lipca 1930, z rąk bpa Ignacego Dubowskiego. Po uzyskaniu doktoratu z teologii, w 1931 powrócił do Polski. W Wadowicach podjął obowiązki jako prefekt gimnazjalistów, nowicjuszy i kleryków profesów. W 1934 został rektorem domu w Chełmnie, gdzie mieściło się Małe Seminarium. Stamtąd dwa razy wyjeżdżał do pracy wśród emigrantów polskich we Francji. W grudniu 1937 wyjechał na stałe. W 1938 założył dom Stowarzyszenia w Amiens. Objeżdżał z posługą duszpasterską departamenty: Somme Seine Inf., Osie; raz w miesiącu dojeżdżał do: Creil, Villers-Saint-Poul, Rouen i Reims. Ponadto był opiekunem Polaków w więzieniach francuskich. Podczas działań wojennych w 1940 opuścił wraz z ludnością Amiens i udał się do Lorient nad Atlantykiem, gdzie pomagał w parafii francuskiej. Powrócił do Amiens, odbudował kaplicę i dom. Od 28 października 1940 do 15 maja 1945, po aresztowaniu ks. F. Cegiełki (26 października), rektora PMK we Francji, pełnił funkcję rektora „ad interim”. 10 lutego 1941 pod zarzutem prowadzenia wrogiej działalności wobec Niemców został aresztowany. Został osadzony w paryskim więzieniu Santé. 31 maja 1941 został zwolniony. $\mathrm{Z}$ jego inicjatywy zainstalowano stację nadawczą w podparyskiej miejscowości Courbevois, która informowała władze polskie o sytuacji w Polsce i martyrologii narodu polskiego. Zorganizował pomoc dla ok. 30 tys. Polaków przywiezionych z całymi rodzinami przez Niemców do północno-wschodniej Francji, celem zatrudnienia w rolnictwie (dep. Meuse, Meurthe et Moselle i w Ardeny). Pomagał im materialnie, zapewnił opiekę duszpasterską i zorganizował sieć polskich szkół. Przed wyzwoleniem 
w lotną dywizję, udzielając w całej Francji rekolekcji i misji. I za tę pracę jesteśmy Mu wdzięczni. Witam ks. [Stanisława] Nowaka ${ }^{20}$, ks. [Mariana] Krupińskiego ${ }^{21}$, który z Bel-

Francji powołał do życia „Miesięcznik Duszpasterski” (maj 1944), w którym przekazywał rodakom wiadomości z życia placówek duszpasterskich i kolonii polskich. W kwietniu 1945 powstał tygodnik Misji „Polska Wierna”. Pełnił funkcję generalnego kapelana PCK we Francji i był członkiem Rady Opieki Społecznej nad Polakami we Francji. Po powrocie ks. Cegiełki z obozu 15 czerwca 1945 poprosił o zwolnienie z urzędu prorektora misji. Powrócił do Misji jeszcze jako rektor ad interim, na krótko po rezygnacji ks. Cegiełki w 1947. 12 października 1947 przekazał agendy rektoratu ks. Kazimierzowi Kwaśnemu. W sierpniu 1945 założył sierociniec, przytułek i dom opieki dla kilkuset polskich dzieci opuszczonych i pozbawionych opieki w Osny, $30 \mathrm{~km}$ od Paryża (Zakład Św. Stanisława Kostki). Założył też tam dom Stowarzyszenia i do 1949 był jego rektorem. Po powstaniu Regii Miłosierdzia Bożego we Francji (1 sierpień 1946) zakupił dom dla potrzeb Stowarzyszenia w Paryżu. W 1. 1949-1952 pełnił urząd superiora Regii, a następnie przeniósł się do Osny, skąd również pełnił posługę duszpasterską wśród polskiej emigracji w dziewięciu departamentach. W 1. 1945-1981 organizował w Osny (przez 37 lat) zjazdy katolickie. Zmarł 30 kwietnia 1982 w Poznaniu. Został pochowany w Kiekrzu na cmentarzu parafialnym. Archiwum Polskiej Misji Katolickiej we Francji. F. Duszpasterstwo. Organizacja duszpasterstwa we Francji okupowanej - ks. Cz. Wędzioch p.o. rektora Misji 1940-1945; G. Duszpasterze Misji - kapelani. IX. 2. Odznaczeni (Czesław Wędzioch); H. Historia duszpasterstwa polskiego we Francji. VII. Życiorysy i jubileusze rektorów Kościoła polskiego, Kościoła w Paryżu i PMK we Francji, 5. Ks. Wędzioch Czesław; N. Zakony i zgromadzenia. IV. Stowarzyszenie Apostolstwa Katolickiego - Księża Pallotyni 1945-1996. 5. Duszpasterstwo polskie we Francji - zjazdy katolickie w Osny (informacje prasowe); P. Personalia. P. II. „Kwestionariusz” prezentujący stan z 20 stycznia 1949, 82. Wędzioch Czesław SAC; P. IV. 46. Wędzioch Czesław, SAC; P. V. 296. Wędzioch Czesław, SAC; P. VI. Ankieta personalna kleru polskiego pracującego we Francji. 1-3. Ankieta personalna z 1945, R-Z, 222. Wędzioch Czesław SAC; W. Certyfikaty - Poszukiwania. I. Certyfikaty. I. 2. Lata 1947-1951. Wędzioch Czesław; Śp. Ks. Czesław Wędzioch, „Duszpasterz Polski Zagranicą” 33(1982), z. 4(145), s. 607-609; S. TyLus, Prace polskich Pallotynów wśród emigracji, s. 469-472, 474-477, 483-484, 488-492, 494-496, 498, 501, 503-506, 508, 516; Materiaty, z. XVIII, s. 94; Duszpasterstwo polskie w świecie. Informator 1970, s. 129, 181; R. Dzwonkowski, Wędzioch Czesław, w: Encyklopedia polskiej emigracji i Polonii, red. K. Dopierała, t. V: S-Ż, Toruń 2005, s. 240; J. SzYmański, Duszpasterze Polonii i Polaków za granica, t. II, s. 194-196.

${ }^{20}$ StanisŁaw NowaK - kapłan archidiecezji krakowskiej. Od 7 sierpnia 1937 podjął posługę duszpasterską w Mulhouse. 1 września tegoż roku podjął obowiązki w tym samym charakterze w Longvy-Gouraincourt. W połowie stycznia 1939 był zmuszony powrócić do Polski z powodu choroby płuc. Archiwum Polskiej Misji Katolickiej we Francji. P. Personalia, 1929-2000, 52. Nowak Stanisław (1937-1939); P. V. Akta osobisto duszpasterskie księży pracujących w ośrodkach duszpasterskich PMK we Francji, gromadzone po 1945. 180. Nowak Stanisław.

${ }^{21}$ MARIAN KRUPIŃSKI - kapłan archidiecezji poznańskiej. Urodził się 6 grudnia 1909 w Koźminie. Syn Józefa i Konstancji z d. Kapuścińska. Po ukończeniu 6 roku życia wstąpił do szkoły powszechnej, następnie naukę kontynuował w Państwowym Gimnazjum Męskim im. T. Kościuszki w Jarocinie. Po uzyskaniu tamże w 1930 świadectwa dojrzałości, wstąpił do Seminarium Zagranicznego, gdzie 15 września 1930 podpisał zobowiązanie, w którym wyraził wolę ,pracowania przez lat dwanaście wśród Polaków zagranicą”. Święcenia kapłańskie przyjął z rąk bpa Walentego Dymka 15 czerwca 1935. 1 lipca 1935 został wikariuszem w Miejskiej Górce, 1 lutego 1936 podjął podobne obowiązki w Piłce. 1 października tegoż roku został przeniesiony na takie samo stanowisko do Połajewa. 1 lipca 1937 został powołany do pracy duszpasterskiej wśród wychodźstwa polskiego w Belgii. Od 1938 pełnił posługę w Sallaumines. 1 marca 1940 był duszpasterzem w Wittenheim (Haut - Rhin). 
gii przybył do Sallaumines, witam ks. [Franciszka] Myszko ${ }^{22}$, który obejmie placówkę w Creusot, ks. [Piotra] Purgoła ${ }^{23}$ oblata, ks. [Wiktora] Krakora ${ }^{24}$ Sekretarza Generalnego

Aresztowany przez Niemców 20 września 1941 w Mulhausen został przewieziony do Dachau (nr obozowy 26333). Zmarł 27 grudnia 1941. Archiwum Archidiecezjalne w Poznaniu, Akta Kurii Metropolitalnej w Poznaniu, Akta personalne, Krupiński Marian Aleksander, KA 9255; Archiwum Polskiej Misji Katolickiej we Francji. G. VII. Wykazy ośrodków duszpasterskich, duszpasterzy, wspólnot zakonnych i statystyki PMK we Francji, 1929-1992. G. VII. 1. Katalogi drukowane (schematyzmy) „Duszpasterstwa Polskiego we Francji” (oraz duchowieństwa): G. VII. 1. 1. Druki 1937/1938; 1939-1961: Duszpasterstwo Polskie we Francji (stan z dnia 15 stycznia 1939); J. Misje - ośrodki duszpasterskie. II. Dekanat Pas de Caleis. 15. Salaumines 1929-1986. 3. Korespondencja 1951-1986; III. Dekanat Nord. 7. Roubaix 1929-1991; E. WeILER, Die Geistlichen in Dachau, s. 379; J. SzYmaŃski, Duszpasterze Polonii i Polaków za granica, t. II, s. 106-107.

${ }^{22}$ FranciszeK MysZKo - kapłan diecezji siedleckiej. Posługę duszpasterską pełnił w: Chaumont, Le Creusot. Archiwum Polskiej Misji Katolickiej we Francji. P. V. Akta osobisto duszpasterskie księży pracujących w ośrodkach duszpasterskich PMK we Francji, gromadzone po 1945. 175. Myszko Franciszek.

${ }^{23}$ PiOtr PuRgOl - kapłan Zgromadzenia Misjonarzy Oblatów Maryi Niepokalanej OMI (oblat). Urodził się 29 sierpnia 1900 w Radzionkowie. Syn Karola i Franciszki z d. Strzelczyk. Szkołę średnią rozpoczął w Radzionkowie, a ukończył w junioracie w Lublińcu (1922-1925). Do nowicjatu w Markowicach wstąpił 14 sierpnia 1925. Po dwóch latach filozofii w Obrze (1926-1928) został posłany do junioratu w Lublińcu, gdzie jako kleryk, który sam studiował, był równocześnie wykładowcą dla juniorów (1928-1932). Święcenia kapłańskie z rąk ks. bp. Stanisława Galla przyjął 21 czerwca 1931 w nowo otwartej kaplicy klasztornej w Lublińcu. Posługę duszpasterską w charakterze misjonarza ludowego podjął w Kodniu (1932). Od lutego do października 1933 jako wikariusz razem z ojcami Janem i Pawłem Kulawymi pełnił obowiązki duszpasterskie w Lubieszowie. Po oddaniu tej placówki został ekonomem w Poznaniu (1934). Wraz z przejęciem klasztoru na Świętym Krzyżu przez rok należał do pierwszej wspólnoty tego klasztoru. W 1937 ponownie wrócił do Poznania, a w następnym roku wyjechał do pracy wśród Polaków we Francji. Drugą wojnę światową przeżył we Francji. Do Polski wrócił we wrześniu 1946. W latach 1946-1949 był proboszczem najpierw w Piekarach, a następnie w Główczycach. Następnie w: Świętym Krzyżu (1949), Lublińcu (1952), Wrocławiu (1954). Na trzech kolejnych placówkach był kapelanem: u sióstr w Wieleniu nad Notecią (1958), w szpitalu na Piaskach we Wrocławiu (1959), w Marysinie k. Gostynia (1959) oraz w Psarach (1963) jako kapelan w domu starców. W 1964 chory powrócił do Poznania. Przez następne lata leczył się w Szklarskiej Porębie, Łodzi, Gliwicach i Plichowicach. Zmarł w szpitalu w Plichowicach k. Gliwic 20 września 1967. Pochowany został na cmentarzu w Bogucicach w kwaterze misjonarzy oblatów. J. NiESŁONY, Stownik biograficzny Misjonarzy Oblatów Maryi Niepokalanej Prowincji Polskiej 1923-2016, Poznań 2016, s. 360-361; Materiaty, z. XVII, s. 147-150.

${ }^{24}$ WiKTOR KRAKOR - kapłan Stowarzyszenia Apostolstwa Katolickiego SAC (pallotyn). Urodził się 24 listopada 1895 w Jedzbarku (niem. Hirschberg), na Warmii. Syn Józefa i Katarzyny z d. Kuk (Kuck). W 1910 rozpoczął naukę w gimnazjum w Wadowicach na Kopcu. Do stowarzyszenia wstąpił w 1920. Studia filozoficzno-teologiczne odbył w Wadowicach (1921-1926) i Limburgu (1926-1927). Święcenia kapłańskie z rąk abpa Adama Stefana Sapiehy przyjął 20 czerwca 1926 w Krakowie. W 1. 1927-1929 odbył studia specjalistyczne w Warszawie. Od 1930 do 1934 był mistrzem nowicjatu braci i rektorem domu w Sucharach, następnie kapelanem sióstr pallotynek i administratorem parafii w Rajcy k. Nowogródka. W okresie międzywojennym okresowo w Wielkim Poście oraz miesiącach letnich pełnił posługę duszpasterską wśród Polaków w Niemczech (1926-1927) i we Francji (1932-1939). W 1. 1938-1939 był sekretarzem PMK. W czasie II wojny światowej pełnił funkcję kapelana żołnierzy Wehrmachtu w Suchej Beskidzkiej i Wadowicach. Po wojnie był duszpasterzem 
Misji. Witam też bardzo serdecznie drogiego i kochanego sąsiada z Londynu ks. rektora Staniszewskiego, sprawującego duszpasterstwo polskie w Anglii, który przybył do nas, aby się z nami pomodlić, Bogu nas polecić i podnieść nas na duchu swoim pogodnym charakterem. (oklaski)

Z kolei chciałbym zdać Księżom sprawozdanie z naszej wspólnej pracy od czasu zeszłorocznego Zjazdu. Na wstępie chciałbym przywołać na pamięć nasze misje ludowe. Nasza ludność, która wytrzymała atak komunizmu tęskniła za misjami. Z Polski przybyli dwaj ojcowie oblaci i dwaj pallotyni, którzy podjęli się trudu przeprowadzenia szeregu misji. Te misje odbyły się we Francji południowej, północnej i wschodniej, gdzie ten ruch popierał szczególnie ks. radca Rogaczewski. Mam nadzieję, że nasz okręg paryski, najgorzej postawiony pod względem duszpasterskim, też będzie mógł przeprowadzić misje na swoim odcinku. Przeżywaliśmy wspólnie radosne chwile widząc powracające zbłąkane dusze naszych braci do Boga. I to było największą nagrodą dla księży, którzy urządzili u siebie te dni uczty duchowej.

Drugie wielkie dzieło to Zjazdy Katolickie. Pierwszy w Montceau, gdzie tak wspaniale udał się przy przepięknej pogodzie, drugi w Hayange z racji 25-lecia ks. Jubilata [Teodora] Makieli ${ }^{25}$. Ten drugi Zjazd dlatego zasługuje na szczególną uwagę, że złożył hołd kapłaństwu i ołtarzowi. W szeregach naszych na Zjeździe znaleźli się przedstawiciele duchowieństwa i władz francuskich, którzy obok rektora i konsula kroczyli razem w pochodzie przez miasto pod polskimi sztandarami. Trzeci wreszcie Zjazd w Wittelsheim. Zjazd ten przybrał specjalny charakter. Miał bowiem za cel uczczenie św. Andrzeja Boboli, a udał

w Gdańsku przy kościele Chrystusa Króla, a potem w Gdańsku-Letniewie (28 wrzesień 1945 1 wrzesień 1947). Tam też był katechetą w miejscowej szkole podstawowej. Następnie podjął posługę w Samsiecznie (1949-1957) i od lutego 1957 w Sobieszewie k. Gdańska (kapelania u franciszkanek służebniczek Krzyża). Przynależał do domu w Gdańsku (ul. Elżbietańska). Zmarł podczas urlopu, w szpitalu w Olsztynie 15 sierpnia 1958. Pochowany został na olsztyńskim cmentarzu św. Jakuba (nieczynny od 1962). S. TYLus, Leksykon polskich pallotynów (1915-2012), s. 292-293.

25 TeOdor Makiela - kapłan archidiecezji katowickiej. Urodził się 8 listopada 1889 w Wirku. Syn Franciszka i Filomeny z d. Kitzka. Uczył się w szkole elementarnej w Wirku, a potem w gimnazjum w Królewskiej Hucie. Świadectwo dojrzałości uzyskał w 1909 i rozpoczął studia na Uniwersytecie Wrocławskim (1909-1912). 21 czerwca 1913 we Wrocławiu przyjął święcenia kapłańskie. Podejmował posługę duszpasterską wobec Polaków we Frankfurcie oraz jako kapelan wojskowy (1913-1915). W 1. 1915-1917 studiował w Berlinie i pełnił obowiązki wikariusza w parafii św. Piotra. Później był wikariuszem w Kamieńcu k. Gliwic (1917-1918), w Katowicach-Dębie (od 28 lutego 1918), i jednocześnie katechetą w szkole nauczycielskiej w Mysłowicach. Od 15 kwietnia 1920 był wikariuszem w Wodzisławiu, od 1 lutego 1923 w Katowicach-Bogucicach. 10 listopada 1924 zgłosił chęć pracy wśród emigracji polskiej we Francji. Zgodę uzyskał w 1925 roku na dwa lata. Co dwa lata przedłużano mu możliwość pozostania we Francji: Caen (od 10 marca 1929), Briey (od 1933), Hayange-Moselle (od 1938). Aresztowany we Francji, zmarł 2 marca 1945 w obozie w Bergen-Belsen. Archiwum Polskiej Misji Katolickiej we Francji. P. V. Akta osobisto duszpasterskie księży pracujących w ośrodkach duszpasterskich PMK we Francji, gromadzone po 1945, 145. Makiela Teodor; P. VIII. Akta Osobowe 1927-2000, 86. Makiela Teodor; H. OlszAR, Polska opieka religijna we Francji w okresie międzywojennym i udział w niej księży diecezji katowickiej, „Wiadomości Archidiecezjalne. Organ Urzędowy Kurii Metropolitalnej w Katowicach” 3(1993), s. 139-143. 
się wspaniale. Te Zjazdy dają nam tę pociechę, iż utwierdzają w przekonaniu, że możemy liczyć na naszą emigrację katolicką i narodową.

Trzeci rodzaj imprez religijnych to pielgrzymki. A więc pielgrzymka na kanonizację św. Andrzeja Boboli do Rzymu. Była to pierwsza ogólno emigracyjna polska pielgrzymka, (wchodzi p. konsul Kawałkowski) aczkolwiek zabrakło w niej przedstawicieli Centralnej Organizacji. Spodziewajmy się, że w następnych naszych pielgrzymkach nie zabraknie tych, którzy pracują w centrali organizacji polskich we Francji i którzy przecież nie raz nam deklamują hymny na cześć katolicyzmu. Inaczej być nie może. Jeżeli my jesteśmy tą największą komórką Centrali, to słusznie się domagamy, żeby ci przedstawiciele byli z nami wtedy, kiedy my święcimy tryumfy życia katolickiego. Będę czuwał i będę się domagał, aby ci panowie w takich naszych imprezach również brali udział. Druga pielgrzymka do Lourdes również mogła nam dać wielką satysfakcję. Była to pierwsza ogólnopolska pielgrzymka z Francji do Lourdes. I trzeba podkreślić, że udana. Wreszcie trzecia pielgrzymka do Lorette, która liczne szeregi Polaków z północnej Francji zgromadziła zwłaszcza w tym roku.

Niech mi jeszcze będzie wolno przywołać na pamięć wspólną całonocną adorację na Montmartre w bazylice Sacré Coeur i wreszcie Tydzień Miłosierdzia Chrzescijańskiego, który w tym roku obchodzić będziemy. Wspominając w tym Tygodniu, proszę Księży, by odczytali z ambon wydaną odezwę w niedzielę $27 \mathrm{bm}$. W odezwie są wyszczególnione cele tegorocznego Tygodnia. To byłyby rzeczy, które chciałem podnieść w słowie wstępnym. Dodam do tego, że nasze wzajemne zjednoczenie, które zasługuje także na uwagę, powinno nas również napawać radością. Możemy być dumni z tego dzieła moralnego zjednoczenia, bo jego następstwem jest to, iż stanowimy jedno serce, i że jedną wspólną owiani jesteśmy myślą. Przyczyni się ono zapewne i do zjednoczenia naszej emigracji w imię hasła „Bóg i Ojczyzna” i do poprowadzenia naszej wspólnej na przyszłość pracy w tym kierunku, by nasza emigracja, podniesiona na duchu i uświadomiona religijnie, mogła stać się naszą chlubą a nie tylko krzyżem. (oklaski)

Powitanie p. Konsula Kawałkowskiego.

Panie Konsulu. Cieszy nas bardzo, że Pan Konsul był łaskaw przybyć na nasz Zjazd w charakterze pełniącego funkcję Radcy Emigracyjnego. Zapewniając Pana Konsula o naszym oddaniu dla naszego państwa, o naszej sympatii do Jego osoby i o woli pomagania Mu swoją pracą duszpasterską do utrzymania patriotyzmu wśród naszych wychodźców, pozwolę sobie przedstawić Panu Konsulowi przy tej okazji pewne prośby. Pierwsza prośba, aby nasi księża nie byli mniej uprzywilejowani od nauczycielstwa. Chodzi o sprawę paszportową. Nam nie chodzi o to, by Państwu nie dać i swego grosza, ale, przez postawienie w taki sposób sprawy opłat paszportowych, muszę z bólem stwierdzić, że zostaliśmy obrażeni w naszych uczuciach patriotycznych. (długie oklaski)

My z naszymi bólami nie będziemy się wypowiadać przed ludem, ale zostawimy je w sercach jako rany. Trzeba nam jednak dać moralną satysfakcję. Jestem przekonany, że Pan Konsul załatwi tę sprawę, bo nam dał już tyle dowodów zrozumienia. $Z$ tą prośbą pozwolę sobie jeszcze raz powtórzyć, że żywimy jak najserdeczniejsze uczucia dla władzy świeckiej i że my tej władzy nie będziemy nigdy stawiać w poprzek w sprawach zasadniczych. (oklaski) 
To była nasza pierwsza bolączka. A jeśli ją tutaj poruszamy, to dlatego ponieważ wszyscy księża zwrócili na nią uwagę, a przedstawiali ją ze smutkiem, że tak mało ceni się ich misję. Te uczucia które wypowiadam, to ból który trzeba wypowiedzieć. My jesteśmy tak bici we Francji, że chcemy by bodaj władze świeckie oceniły nasze wysiłki.

Ale jest druga sprawa, którą pragnę jeszcze przedstawić. W naszych warunkach duszpasterskich coraz nam gorzej. Są placówki bez uposażenia. Tę sprawę przedstawiłem już Panu Ambasadorowi, który odniósł się do niej życzliwie, zaznaczając, że poruczy ją panu Konsulowi Kawałkowskiemu dla dalszego załatwienia. Pracujemy dla Boga i dla Polski i gdyby nas tutaj nie było, ciężka byłaby sytuacja placówek konsularnych. Nam, którzy pracujemy z poświęceniem i dla Państwa polskiego powinno Państwo dopomóc, bo nie tylko słowem Bożym żyją księża, ale i chlebem. Były wypadki, że księża polscy (jak ks. [Tadeusz] Kirschke ${ }^{26}$ ) jedli raz w tygodniu ciepły obiad za 6 fr. Na te wypadki zwracam uwagę i sadzę, że nie będą one miały miejsca, gdy Pan Konsul przedstawi te sprawy w Warszawie, by otrzymać dla nas pomoc materialną. My się nie wstydzimy o tę pomoc prosić, bo to jałmużna naszych braci. Państwo otrzymuje pieniądze nie z nieba, ale od obywateli i dlatego prosimy, aby połamano się z nami tym chlebem, którzy obywatele polscy składają dla państwa polskiego. (oklaski) Oddając głos Panu Konsulowi, proszę go o skierowanie do księży kilku słów wyjaśnienia.

Przemówienie Konsula Generalnego P. Kawałkowskiego.

Czcigodni Księża. Będąc zaproszonym pozwoliłem sobie przyjść nieco wcześniej dlatego, że o 11 odchodzi mój pociąg, a muszę wcześniej wyjechać. Jeżeli ks. rektor pozwoli, to zanim przejdę do spraw, chciałbym powiedzieć kilka słów z tytułu urzędu jaki sprawuję. Jest rzeczą bardzo ważną, aby między nami było zrozumienie wzajemne. Miałem już możność zabierać głos na północy. Proszę księży ja chciałbym abyście księża nabrali przekonania co do jednej rzeczy. Tak, jak w kraju, tak i na terenie emigracyjnym wyszli-

${ }^{26}$ TADEUSZ KIRSCHKE - kapłan archidiecezji poznańskiej. Urodził się 20 września 1908 w Głównej (obecnie dzielnica Poznania). Syn Stanisława i Marii z d. Bobkiewicz. Po uzyskaniu świadectwa dojrzałości w gimnazjum św. Marii Magdaleny w Poznaniu, podjął studia filozoficzno-teologiczne w Wyższym Seminarium Duchownym w Gnieźnie i w Poznaniu. 17 czerwca 1934 w katedrze poznańskiej przyjął święcenia kapłańskie z rąk kard. A. Hlonda. Podjął obowiązki wikariusza w Objezierzu i Kępnie. Od 1935 był duszpasterzem polonijnym we Francji, początkowo w Paryżu, a następnie w Audincourt. W 1939 został dyrektorem Związku KSMP we Francji. W czasie II wojny światowej był kapelanem w 2 Dywizji Polskiej we Francji. Został internowany w obozie jenieckim w Murnau, a następnie skazany na karę śmierci i osadzony w obozie koncentracyjnym w Flossemburgu. Od 1947 przebywał w Wielkiej Brytanii, gdzie był naczelnym asystentem kościelnym Polskiego Katolickiego Stowarzyszenia Uniwersyteckiego „Veritas” w Londynie 1948-1952. Od 1952 pracownik rozgłośni Radio Wolna Europa w Monachium. Po przejściu na emeryturę (1977) powrócił do Londynu. Odznaczony został: Orderem Odrodzenia Polski (IV), Złotym Krzyżem Zasługi z Mieczami, Srebrnym Krzyżem Zasługi z Mieczami, Medalem Wojska. Zmarł 15 kwietnia 1996 w Londynie. Archiwum Polskiej Misji Katolickiej we Francji. P. V. Akta osobisto duszpasterskie księży pracujących w ośrodkach duszpasterskich PMK we Francji, gromadzone po 1945. 100. Kirschke Tadeusz; A. Siomkajıo, Kirschke Tadeusz, w: Encyklopedia polskiej emigracji i Polonii, red. K. Dopierała, t. II: $F-K$, Toruń 2003, s. 404-405. 
śmy już z okresu, kiedy ścierały się doktryny polityczne, a ludzie zadawali sobie pytanie, jaką pójść drogą. Te spory, jeśli chodzi o czynniki miarodajne, już nie istnieją. Nasza droga to droga ścisłej współpracy między Kościołem a Państwem, współpracy opartej na idei etyki chrześcijańskiej. Tego rodzaju idea przewodzi w Polsce dziś. W tym kierunku chcemy prowadzić naszą pracę na emigracji. Emigracja, która nie bierze udziału w głosowaniu, która nie ma wpływu na przebieg wydarzeń w Polsce nie może być grupowana na podstawie kryteriów politycznych. Ona musi być grupowana tak, aby ją zachować dla polskości. Stąd postulat aby ją grupować. Od roku polityka emigracyjna krystalizuje się. Jeżeli chodzi o formę organizacyjną, jeżeli chodzi o pracę oświatową, to ona nie może się odbywać na zasadach sprzecznych z zasadami religijnymi. W opracowaniu statutu tworzącego się Związku Polaków we Francji, statut przewiduje, że Związek będzie pracował na platformie katolickiej i narodowej. To będzie kręgosłupem. Uważam, że nie będzie można liczyć nigdy na to, aby połączyć pogląd katolicki i marksistowski, ponieważ nie mielibyśmy możności wychowania emigracji w duchu narodowym, opartym na zasadach katolickich.

Z tytułu funkcji urzędowych otaczamy opieką wszystkich obywateli. Jeżeli chodzi o organizacje marksistowskie, to członkom udzielamy oczywiście opieki urzędu polskiego, natomiast współpracę będziemy dawać tylko tym czynnikom, które mają wyraźny pogląd. Księża przecież poszczególnym jednostkom pociechy nie odmawiają. Mielibyśmy jednak serdeczną prośbę pod adresem księży, aby księża otaczali w koloniach opieką wszystkie organizacje wchodzące w skład Związku Polaków. Jest to ważne proszę księży, ponieważ w ramach tego frontu będą organizowane wszystkie czynniki katolickie i narodowe. Osobiście uważam wpływ w tym kierunku jako najowocniejszy współudział z Kościołem. Mogą mi księża wierzyć, że jeżeli chodzi o patrzenie na dłuższą metę, to jestem przekonany, że ta współpraca między księdzem a nauczycielem będzie zupełna. W związku z tym proszę o opiekę nad wszystkimi organizacjami polskimi. Ja stwierdzam na północy ciekawy objaw. Ten ksiądz, który ogranicza się akcji do tworzenia Akcji Katolickiej, to promień oddziaływania tego księdza skraca się. On nie oddziałuje na wszystkich, izoluje się od reszty kolonii. Chodzi nam przecież o to, aby mieć wpływ na całą kolonię. Mnie się zdaje, że jest przecież do pomyślenia, by oddziaływać na wszystkie organizacje. Wtedy będziemy mieli wynik tego rodzaju, że wszystkie Stowarzyszenia będą miały zaufanie do księdza i ksiądz ciesząc się dużym zaufaniem ma możność przenikania do wszystkich Stowarzyszeń, które w przeciwnym razie nie mogły przyjść pod jego opiekę. W przeciwnym razie tworzą się w kolonii dwa bieguny, koło księdza jeden, drugi dookoła nauczyciela. Jeżeli razem pracują, to nauczyciel będzie jego ramieniem działania. Ja daję gwarancję, że w organizacji Frontu Narodowego nie będziemy mieli marksistowskiego czynnika, chociażby te organizacje stały na gruncie państwowo-polskim. Nam chodzi aby Front Narodowy miał pewne oblicze ideologiczne. To prośba moja o charakterze zasadniczym. Jestem pewny, iż jeżeli księża zrozumieją, iż nasze dążenia są wspólne, znikną małe drobiazgi, a księża zapewniwszy wszystkim Towarzystwom pomoc, nie będą mieć w kolonii przykrych historii. Chciałbym doprowadzić do tego, aby konfliktu nie było. - Jeżeli chodzi o prośbę o pomoc konkretną i jej udziału w świadczeniach materialnych, to my mamy pewien postulat. Chodzi nam o to, że podstawą roboty świeckiej jest szkoła polska. Oto chcę skorzystać z okazji by księży poprosić, aby księża $\mathrm{w}$ okresie zbiórki na oświatę rozwijali akcję z ambony, jak również daniem przykładu dla wiernych. Jestem przekonany, że zbiórka na ten cel znajdzie u księży 
pełne zrozumienie, a wyniki jej będą wydatne. Teraz poruszę sprawę, którą ksiądz rektor poruszył. Chciałbym zaapelować do księdza rektora, aby ksiądz rektor zgodził się ze mną. Jest wiele spraw nieuregulowanych. Chciałbym aby panowała pewna atmosfera. $\mathrm{O}$ tym aby czynniki urzędowe zmierzały do obrażenia uczuć księży nie ma mowy. Przedstawia się sprawa w ten sposób, że księża znają biurokratyzm. Jeśli chodzi o dziedzinę paszportową, to można to zmienić, ale dopóki obowiązuje, musi się zachować. Tej sprawie nadałem już bieg stosowny do życzeń księży i zwróciłem się do Warszawy o zmianę tych przepisów. Nie myślę bowiem, aby odgrodzić od tych świadczeń księży. Uprzedzając zarządzenie Ministerstwa poszliśmy na rękę księżom tak, że już każdy może dostać paszport bezpłatny. Jeżeli chodzi o pozostałe sprawy, o pomoc dla Misji, to mam jak najlepsze intencje, jeżeli mi się da uzyskać nowe środki. Mogą być księża przekonani i proszę mi wierzyć, że zadanie Misji Katolickiej leży na sercu P. Ambasadorowi i nam Konsulom. Jeżeli chodzi o ustalenie zasad, to nie będzie różnic, ani sprzeciwu. Jeżeli chodzi o zrealizowanie tej pomocy to obracamy się w szczupłym zakresie możności finansowania, ale może nie za długo da się to zrealizować. Mogę jednak księży zapewnić, że włożę maksimum wysiłku, aby możliwie w krótkim czasie przyjść Misji Katolickiej z pomocą.

Księże rektorze. Pozwolę sobie złożyć jak najserdeczniejsze życzenia obradom i prosić o to, by przy rozpatrywaniu wzięto pod uwagę moje życzenia, a szczególniej tę zasadniczą pierwszą prośbę, że całość pracy narodowej zależy od wyrobienia religijnego. Jestem przekonany, że w tej atmosferze życia narodowego zrealizują księża postulaty życia katolickiego. A to natężenie w pracy ma być nastawione i oparte na nucie czynnika religijnego, albowiem to natężenie życia religijnego daje siłę przeciw czynnikom, które nam grożą ze Wschodu i Zachodu.

Ksiądz rektor odpowiadając P. Konsulowi dziękuje i oświadcza, iż jego przemówienie nie tylko nas uspakaja, ale wprowadza w nasze stosunki pełną harmonię. Myśmy - mówi ks. rektor - mieli obawy, że do Związku Polaków wejdzie T.U.R. ${ }^{27}$, ale to cośmy usłyszeli, daje nam gwarancję, że bez wszelkiej obawy, możemy podpisać akces do Związku.

Równocześnie dziękuję za to, że p. konsul był łaskaw wziąć do serca dwa postulaty nasze: duszpasterski i materialny. Na zakończenie - mówi ks. rektor - składam życzenia, aby Pan Konsul czuł się wśród nas jak najlepiej i zapewniam Go, że może liczyć na szeregi duchowieństwa polskiego. Księża Pana Konsula nie zawiodą. Wznoszę okrzyk. Pan Konsul niech żyje. (okrzyk podnosi sala, potem oklaski i p. konsul odchodzi żegnany przez wszystkich)

Przemawia z kolei ks. prałat Kaczyński.

Pragnę jak najserdeczniej podziękować wszystkim Czcigodnym Konfratrom, za serdeczne i miłe przyjęcie, jakiego doznałem. Przywożę ze sobą powiew Ojczyzny i pozdrowienie szczególnie ze strony J. Em. Ks. Kardynała Kakowskiego, który mi polecił pozdrowić księży i podziękować za trudy, jakie ponoszą we Francji. Proszę wierzyć, że praca księży jest oceniana w Polsce zupełnie dobrze. Mamy dobre informacje, a czerpiemy je od swoich i od obcych. Dla nas jest miarodajna znajomość księży, którzy idą do Francji nie

27 Towarzystwo Uniwersytetów Robotniczych. 
po życie wygodne i aby dorobić się majątku, ale idą do Francji, aby nieść ideę służby dla Boga i Ojczyzny. Wiemy w jakich warunkach żyją nasi księża tutaj we Francji. Wnikamy bardzo blisko w stosunki waszej pracy, jak również zdajemy sobie sprawę z trudności i niebezpieczeństw, na jakie są księża narażeni. My zdajemy sobie sprawę z trudności waszych we Francji już od dawna, gdy wiedzieliśmy, że księża woleliby pracować wśród dzikich ludów, niż tu u siebie. Więc dlatego też działalność księży oceniana jest w Polsce zupełnie dobrze i zrozumiale. Episkopat polski daje dowód najwyższego uznania dla Was wszystkich. Chciałbym w kilku słowach nakreślić obraz sytuacji w Polsce. Jak już księża słyszeli z przemówienia konsula wytwarza się w Polsce kurs współpracy Kościoła z Państwem. Już od 3 lat kurs ten idzie, aby wytworzyć psychikę współpracy. Niedawno byłem na poświęceniu kościoła w Spale. Rozmawiałem z p. Prezydentem Rzeczypospolitej, który mi powiedział: „Niech ksiądz wszędzie powie, że zasadniczym postulatem państwa polskiego jest wnieść ideały chrześcijańskie do życia publicznego w Polsce". - Podobne tendencje wypowiedział Marszałek Śmigły-Rydz. Niedawno mieliśmy trudne chwile, kiedy Kościół był jawnie prześladowany, była akcja ze strony nauczycielstwa idąca w kierunku bezbożniczym dla usunięcia wpływów katolickich z wychowania, była akcja za popieraniem sekciarstwa, które nawet finansowano, walka ze starostami i duchowieństwem, w tym kierunku i minister wysilał się, aby gnębić księży za kazania. Oto ta polityka jak mogły się przekonać sfery miarodajne wyrządziła szkodę Państwu i wskutek niebezpieczeństwa grożącego Polsce, polityka czynników katolickich zwyciężyła, więc też mamy teraz zrozumienie i współpracę. Ta współpraca ma się jednak pogłębiać. Widzimy duży sukces dzięki temu, że usunięto przeszkody. Obserwujemy duży rozwój Akcji Katolickiej. W Akcji Katolickiej mamy pół miliona osób, 300000 młodzieży męskiej, 250000 dziewcząt, pomijając Bractwa Kościelne. Następnie życie organizacyjne pogłębia się wewnętrznie. Widać to ze zestawienia rekolekcji zamkniętych. Liczba tych rekolekcji stale się powiększa. W zeszłym roku według statystyki odprawiło rekolekcje zamknięte przeszło 120000 osób. Czcigodni księża widzą, że jest to poważna cyfra przy małej ilości domów rekolekcyjnych. Widzimy nadto ruch w kierunku pogłębienia życia religijnego $\mathrm{u}$ inteligencji. Powstały już we wszystkich diecezjach Instytuty Wyższej Kultury Religijnej. Jest to szereg wykładów teologii w metodach uproszczonych. Zjawisko, że na kurs 3 letni zapisało się w Warszawie przeszło 15000 osób z inteligencji świadczy o postępie inteligencji na drodze do pogłębienia religijnego życia. Powstały niedawno zakon „Krzyża i Miecza”, którego zadaniem jest rozwój życia katolickiego z działalnością na zewnątrz. Rokuje on dobre nadzieje na przyszłość.

Święciliśmy niedawno dzień przyłączenia Zaolzia do Polski. Rozmawiałem na ten temat z dziennikarzami francuskimi. Mówiłem, że Polska zaproponowała 35 razy porozumienie z Czechosłowacją. Jeżeli Polska zmuszona była do podjęcia tych kroków jak ostatnio, to nic innego jak tylko polityka Czechosłowacji nas do tego zmusiła.

Nasza wspólna współpraca nas duchownych i świeckich zdąża do tego, aby Polska była silna. My w Polsce zdajemy sobie dobrze sprawę, że jeżeli Pan Bóg nam nie dopomoże i my sami sobie, to nikt nam nie dopomoże. My księża dajemy na dozbrojenie naszej Armii. My w Polsce zbroimy już nadbałtyckie państwa i Bałkany. Powstał cud naszej pracy. Gdynia i Centralny Okręg Przemysłowy. (C.O.P.) gdzie już nie w tempie amerykańskim, ale $\mathrm{w}$ tempie polskim wre praca. Stoimy z bronią u nogi. Topnieją szeregi bezrobotnych. 
Stać nas na drugi C.O.P. z racji przyłączenia Zaolzia do Polski. Przed Polską są duże możliwości, bo mamy naród zdrowy. Tu we Francji mamy istoty, ale bez krwi. W Polsce najważniejszym zagadnieniem to kwestia żydowska. My nie możemy jej traktować jak Niemcy, bo to nie byłoby godnym naszego narodu o wysokiej kulturze chrześcijańskiej. Musimy się starać wytłumaczyć kwestię żydowską Francuzom, chociaż tutaj u steru rządu stał Żyd, Blum. W Polsce mamy 3 i pół miliona Żydów. Niepodobna abyśmy wyrzucali poza granicę najlepsze nasze siły naszych ludzi, a siły niepewne zatrzymywali. Kwestia żydowska musi być rozwiązana przez emigrację Żydów. Rozwój przemysłu polskiego i handlu idzie w szybkim tempie. Muszę powiedzieć, że ostatnio np. w Brześciu 9 poznaniaków otwarło sklepy nowe i $9 / 10$ manufaktury jest w rękach polskich. U nas samo życie bez nacisku idzie w kierunku rozwiązania kwestii żydowskiej. Oto położenie w Polsce ogólnie tylko scharakteryzowane. - Jestem wdzięczny przede wszystkim za tak miłe przyjęcie i proszę przyjąć zapewnienie, że łamy prasy katolickiej są dla Was otwarte. Podkreślając pracę księży wypełniam obowiązek wdzięczności za Wasze trudy i bądźcie przekonani, że całym sercem będziemy dla Was i z uznaniem za Waszą pracę. (liczne oklaski)

W odpowiedzi na przemówienie dziękuję ks. prałatowi serdecznie. Ks. rektor nadmieniając, że rozumie uczucia J. Eminencji Ks. kardynała, który przyjmując do swej diecezji zgromadzenia zakonne stawił warunek, iż będą wysyłały księży na pracę wśród emigrantów. Proszę Go zapewnić - mówił ks. rektor - że doceniamy Jego arcypasterskie serce i wdzięczni jesteśmy za pamięć. Dziękuję raz jeszcze za „expose” o Polsce i serdeczne uczucia braterskiej łączności, wznosząc okrzyk. K.A.P. i duchowieństwo polskie w kraju niech żyją (huczne oklaski) odgłosy „precz z Gazetą Kościelną”.

Z kolei odczytano list - orędzie J. Eminencji Ks. Prymasa, który wszyscy zgromadzeni powstawszy wysłuchali, witając pozdrowienie i błogosławieństwo J. Eminencji niemilknącymi oklaskami. Następnie odczytano listy z życzeniami od ks. rektora Posadzego, ks. dra Świetlińskiego, ks. dra Olszewskiego z Warszawy.

I. Ref. Po odczytaniu listów ks. rektor prosi ks. dziekana Rogaczewskiego o wygłoszenie odczytu pt. „Warunki powodzenia duszpasterstwa polskiego we Francji”. Przyszliśmy mówi referent - aby tu zachować u naszych Rodaków wiarę i mowę ojców. Towarzyszą nam w pracy życzenia Biskupów polskich i troska J. Em. Ks. Prymasa, który założył Seminarium Zagraniczne. Metody naszej pracy różne są od krajowych. Nie mamy parafii, nie mamy dostępu do szkoły. Mimo tych warunków nie powinniśmy upadać na duchu, a ponieważ warunki naszej pracy nadzwyczajne, dlatego powinniśmy wykazać, żeśmy dorośli do tej nadzwyczajnej pracy. W swojej pracy musimy dążyć do osiągnięcia powodzenia w duszpasterstwie w ogóle a w polskim w szczególności. By towarzyszyć mogło powodzenie w duszpasterstwie w ogólności trzeba stosować środki zwyczajne i nadzwyczajne. Zwyczajne środki: to nabożeństwa, kazania, sakramenty święte, organizacje, katechizacja dzieci. Od tego jak te funkcje kapłańskie spełnimy, zależeć będą sukcesy. Rozumie się, że łaską swoją, wspiera Bóg tych, którzy chcą coś zrobić.

Nadzwyczajne środki to misje ludowe i rekolekcje. W swojej pracy musimy uwzględniać także rekolekcje zamknięte, które dziś są, dla naszych działaczy zwłaszcza, naglącą 
koniecznością. Jeśli chcemy zachować żywą wiarę w naszych ludziach dajmy im możność nabyć tej żywej wiary w ciszy domu rekolekcyjnego.

Polska akcja duszpasterska. Jak celem duszpasterstwa w ogóle powinno być zachowanie wiary ojców tak celem polskiego duszpasterstwa powinno być zachowanie patriotyzmu i mowy ojców. Do zachowania łączności polskiej na emigracji mają nam służyć takie imprezy religijne jak: Zjazdy Katolickie, pielgrzymki wspólne do Częstochowy, Lourdes czy Rzymu, wspólna adoracja na Montmartre i Tydzień Miłosierdzia Chrześcijańskiego.

Nie małą spójnią powinny być dla nas Wiadomości Parafialne, które musimy rzetelnie popierać, by mogły się rozróść. Wielką rolę odgrywa także w tym kierunku pielęgnowanie polskiego śpiewu religijnego.

Kończy referat życzeniem, by Dobry Bóg raczył przyjąć ofiarę naszej pracy.

Dziękując za prześliczny referat, proponuje ks. rektor przedruk tegoż dla użytku konfratrów. Ks. dziekan Rogaczewski przyjmuje obowiązek nadesłania swego referatu wszystkim księżom. Następnie ks. rektor zaznacza, że Francja północna już przygotowuje Kurs rekolekcyjno-religijny dla młodzieży, na cele czego złożono już składkę ze święta Chrystusa Króla. Co do sprawy Wiadomości Parafialnych poruszonych w referacie zaznacza ks. rektor, że ich redaktor ks. [Kazimierz] Kwaśny ${ }^{28}$ wpadł w pewien pesymizm i zrzeka się stanowiska redaktora. Ale bądźmy dobrej myśli, że nasz kochany redaktor spotka się z większym poparciem ze strony księży i swoje stanowisko zatrzyma. (oklaski dla ks. Kwaśnego)

Ks. rektor otwiera dyskusję nad referatem. Zabiera głos ks. Szewczyk, który jako dyrektor Zw. Bractw Różańcowych przypomina się z medalikami, tajemniczkami i świeżo

${ }^{28}$ KAZIMIERZ KwAŚNY - kapłan (archi)diecezji przemyskiej. Urodził się 16 stycznia 1900 w Dukli. W 1917 ukończył gimnazjum w Jaśle. Był żołnierzem armii austriackiej i legionistą. Podczas służby wojskowej rozpoczął studia filozoficzno-teologiczne. Święcenia kapłańskie przyjął 23 maja 1923 w Przemyślu. Od 1 sierpnia 1923 został wikariuszem w parafii Czudec, a od 1 sierpnia 1925 wikariuszem w Pysznicy. Od 17 sierpnia 1925 do 26 sierpnia 1926 był ekspozytorem (organizował i administrował parafią w Jastkowicach). Ponownie został wikariuszem w Przeworsku (do 1 lipca 1930). Od 1 września 1930 objął placówkę wśród wychodźstwa polskiego we Wschodniej Francji, w Audun-le-Tiche. W czasie II wojny światowej został wysiedlony z parafianami do Loudun (Vienne). Tam duszpasterzował dla Polaków i Francuzów. W 1945 wrócił do Audun-le-Tiche i został dziekanem Wschodniej Francji. 12 października 1947 został rektorem Polskiej Misji Katolickiej we Francji. W powojennych warunkach, bez subwencji z Ojczyzny organizował działalność Misji. Założył Kongres Polonii Francuskiej, Polskie Zjednoczenie Katolickie, skupiające prawie wszystkie organizacje i stowarzyszenia we Francji. Został uhonorowany godnością kanonika kapituły katedralnej przemyskiej, prałata (1949) i protonotariusza (infułata - 1963) Jego Świątobliwości i francuskim odznaczeniem Ordre de la Santé Publique. W 1972 z powodów zdrowotnych przeszedł na emeryturę i zamieszkał w Paryżu. Zmarł 23 listopada 1987. Pochowany na cmentarzu Montmorency pod Paryżem. Archiwum Archidiecezjalne w Przemyślu, Akta personalne księży. Teczka personalna: ks. Kwaśny Kazimierz; Śp. Ks. inf. Kazimierz Kwaśny, „Duszpasterz Polski Zagranicą” 39(1988), z. 1, s. 152-155; K. Dopierala, Kwaśny Kazimierz, w: Encyklopedia polskiej emigracji i Polonii, red. K. Dopierała, t. III: K-O, Torun 2004, s. 104; A. et Z. Judycki, Les Polonais en France. Dictionnaire biographique, vol. I, Paris 1996, s. 113; S. Zych, B. WALICKI, Ksiądz Kazimierz Kwaśny, rektor Polskiej Misji Katolickiej we Francji (1900-1987). Przyczynek do biografii, „Przegląd Polsko-Polonijny” 2013, nr 5-6, s. 447-456; J. SzYMański, Duszpasterze Polonii i Polaków za granica, t. I, s. 89-90. 
wydanymi ustawami dla Bractw, które liczą obecnie na podstawie dokonanej ostatnio statystyki 12110 członkiń. Proponuje by czytanki różańcowe ukazywały się w „Wiadomościach", prosząc by konfratrzy lekkiego pióra zechcieli nadsyłać do nich materiał.

Ks. [Leon] Plutowski ${ }^{29}$ nawiązując do przemówienia p. konsula, iż powinniśmy się zająć wszystkimi organizacjami w koloniach jest zdania, iż przede wszystkim Katolickimi Towarzystwami mamy się zająć, gdyż o tyle nas inni będą szanować, o ile nasze organizacje stać będą wysoko. O ile p. konsul tak po katolicku wyraził się o naszej pracy to tylko dzięki naszemu wysiłkowi, gdyż były tendencje by do Związku Polaków we Francji należał również i T.U.R. My możemy należeć do Związku Polaków, o ile statut tegoż oparty będzie na zasadach katolicko-narodowych.

Ks. [Jan] Glapiak ${ }^{30}$ thumaczy się w sprawie pielgrzymki do Lourdes.

Dyskutują potem księża nad terminem pielgrzymki do Lourdes i wyrażają uznanie ks. Kwaśnemu za redakcję „Wiadomości Parafialnych” po czym dyskusję zamknięto.

II. Referat ks. dyr. Makulca pt. Wytyczne w pracy organizacyjnej wśród dzieci polskich we Francji.

Nawiązując do czasów obecnych jako ,wieku dziecka” wspomina o wszystkich imprezach rozwijających ciało, a zapoznających duszę dziecięcą. Państwo chce zmonopolizować wychowanie dziecka. Tymczasem Kościół pierwszy był wychowawcą dziecka zakładając szkoły, przytułki. Po Kościele rodzice mają obowiązek wychowania religijnego dzieci. Jaka powinna być wytyczna w naszej nad dziećmi pracy. Dzieci są najważniejszą cząstką

${ }^{29}$ LeON Plutowski - kapłan archidiecezji gnieźnieńskiej. Urodził się 6 grudnia 1908 w Bydgoszczy. Święcenia kapłańskie przyjął 17 czerwca 1934. Od 1 lipca został wikariuszem w parafii św. Józefa Oblubieńca NMP w Inowrocławiu. Od 31 lipca 1935 podjął posługę duszpasterską we Francji. Przez pierwszy rok pracował w Roubaix, a od następnego roku w Harnes. W 1. 19591961 był proboszczem w Dziewierzewie. Zmarł 13 czerwca 1989. Pochowany został na cmentarzu św. Stanisława Kostki w Poznaniu. Archiwum Polskiej Misji Katolickiej we Francji. P. II. „Kwestionariusz" prezentujący stan z 20 stycznia 1949. 55. Plutowski Leon; P. IV. Ankieta personalna księży pracujących w ośrodkach duszpasterskich PMK w 1943; [52 odpowiedzi]; 32. Plutowski Leon, diec. Gnieźn.; ur. 6 XII 1908 Bydgoszcz; św. 17 VI 1934 Poznań; we Francji od 31 VII 1935; praca; Roubaix, jeden rok; Harnes, siedem lat [od 1936]; mieszka w Harnes; dusz: ok. 4500; P. V. Akta osobisto duszpasterskie księży pracujących w ośrodkach duszpasterskich PMK we Francji, gromadzone po 1945. 208. Plutowski Leon; P. VI. Ankieta personalna sporządzona w 1945. 161. Plutowski Leon.

30 JAN GLAPIAK - kapłan diecezji Arras (Francja). Urodził się 27 marca 1906 w Westfalii, gdzie rozpoczął naukę gimnazjalną. Do Francji przyjechał z rodzicami w 1923. Dalsze studia kończył w seminarium duchownym w Arras, gdzie przyjął święcenia kapłańskie 11 lipca 1929. Pierwszą Mszę św. prymicyjną odprawił w Grenay, gdzie po przyjeździe z Niemiec osiedlili się jego rodzice. 27 września 1929 objął placówkę duszpasterską w Lens, gdzie pracował do 10 sierpnia 1942. Następnie, w czasie okupacji niemieckiej objął największą parafię polską w Oignies - Ostricourt, biorąc czynny udział w pracy społecznej i w polskim Ruchu Oporu P.O.W.N. W roku 1949, na własne życzenie przeniesiony został do pracy duszpasterskiej w małej wiosce Ayette (P. de C). Zmarł 11 lipca 1958. Archiwum Polskiej Misji Katolickiej we Francji, P. Personalia, IV. Ankieta personalna księży pracujących w PMK we Francji 1943, Kwestionariusz do wypełnienia i odesłania do Pol. Misji Kat. w Paryżu Jan Glapiak; Śp. Ks. Jan Glapiak, „Duszpasterz Polski Zagranicą” 9(1958), z. 4(37), s. 449; R. Dzwonkowski, Przemiany polskiej parafii w pólnocnej Francji (1922-1972), s. 50. 
naszych parafii. Najwięcej powinniśmy im poświęcić czasu i trudu dążąc do wysokiego w nich wyrobienia religijnego przy pomocy naszych organizacji. Powtórzyliśmy w naszych parafiach wiele organizacji starszych, które mogą nas wyręczać czasami w naszej pracy nad dziećmi. Jako jedyna organizacja dziecięca na wychodźstwie to Stowarzyszenie Dzieci Rycerstwa Chrystusowego. W Polsce mamy 195000 w Krucjacie Eucharystycznej ..... wchodzi na salę J.E. Pan Ambasador

Ks. rektor przerywa referat i wita Pana Ambasadora a potem przemawia. Panie Ambasadorze. Serdecznie Pana Ambasadora na naszym Zjeździe witamy i uprzejmie dziękujemy za łaskawe przybycie. Pan Ambasador w ostatnim roku okazał dużo zainteresowania pracą kapłanów polskich, dużo sympatii i uczuć przyjacielskich dlatego i za to składam mu gorące uczucia wdzięczności w imieniu zebranych księży. Dziękuję zwłaszcza za chęć dopomożenia nam swoją interwencją u pana ministra Monzie w sprawie pensji, którą po dniach wrześniowych jednemu księdzu wstrzymano. Ta gotowość Pana Ambasadora wzruszyła nas i utwierdziła w przekonaniu, iż w Panu Ambasadorze ma tutejsze duchowieństwo polskie serdecznego i oddanego przyjaciela (oklaski).

Obok podziękowania niech mi będzie wolno złożyć Panu Ambasadorowi serdeczne gratulacje z powodu odniesionych przez niego sukcesów na stanowisku dyplomatycznym. A więc najpierw gratulacje za zwycięstwo w sprawie Litwy. Przeżyliśmy silny atak prasy i opinii francuskiej na Polskę w pamiętnych dniach marca bieżącego roku. Że te ataki ustały, to nie mała zasługa Pana Ambasadora, który często musiał chodzić na Quai d' Orsay, by Francji przedstawić stanowisko Polski.

Po burzliwym maju przyszły dni wrześniowe. I wtedy czuwał Pan Ambasador. Wczuwaliśmy się $\mathrm{w}$ jego położenie kiedy musiał przekonywać sterników rządu francuskiego i powtarzać te prawdy, które ich z trudnością przekonywały. Te dni wrześniowe były trudne ze względu na położenie naszej emigracji. Pan Ambasador doprowadził do tego, że francuski minister w przemówieniu radiowym wyraził pełne uznanie dla robotnika polskiego we Francji. My Mu tego nie zapomnimy nigdy. Może być przekonany, że zdobył serca duchowieństwa polskiego we Francji. Niech więc będzie łaskaw przyjąć te gratulacje i życzenia coraz to nowych jeszcze zwycięstw. Ale mamy i dług wdzięczności za sympatię i pomoc, w walce $\mathrm{z}$ wrogiem, jakim jest komunizm. Pan Ambasador utrącił wroga jakim był „Dziennik Ludowy”31. Krok Pana Ambasadora dlatego tak serdecznie oceniamy, ponieważ my kapłani polscy najwięcej narażeni byliśmy na ataki i odczuwaliśmy ich skutki na sobie. Niech Pan Ambasador będzie przekonany, że Jego silne ramię będziemy podtrzymywać i dopomagać, aby to zwycięstwo stało się trwałe.

Wraz z gratulacjami wyrażamy uczucia radości z powodu poprawy stosunków ekonomicznych w kraju, stworzenia wielkiego dzieła, jakim jest C.O.P. i powrotu Zaolzia do Macierzy. Cieszymy się, że liczna gromada rodaków ze Śląska mogła powrócić w granice

${ }^{31}$ Pod koniec 1936 roku wydawany przez komunistów „Dziennik Ludowy” stał się jedną z najpoczytniejszych gazet codziennych wśród Polonii francuskiej, a powstające koła przyjaciół „Dziennika Ludowego" (liczące około 10 tys. członków) były istotnym instrumentem działalności politycznej. Komuniści występowali przeciwko polityce władz, zarówno w Polsce, jak i we Francji, krytykując m.in. niedostateczną opiekę konsularną. Cyt. za: Zjazdy i konferencje konsulów polskich we Francji. Protokoły i referaty 1931-1938, oprac. H. Chałupczak, E. Kołodziej, Lublin 2009, s. 25. 
Ojczyzny. Niech droga nasza Ojczyzna odnosi nadal takie sukcesy. Niech i Pan Ambasador zbiera liczne plony w swojej dalszej pracy. Nasze oddanie, radość kapłańska i pomoc nasza towarzyszyć będzie Panu Ambasadorowi we wszystkich Jego czynnościach dyplomatycznych. Zwycięstwa i radości Pana Ambasadora staną się też naszymi radościami. Niech Jego praca idzie w dalszym ciągu zwycięsko i niech i w tym roku Bóg Mu błogosławi. Rzeczpospolita Polska i Jej Przedstawiciel „Niech żyją” (okrzyk i oklaski).

Pan Ambasador w odpowiedzi na powitanie przemawia.

Przewielebny Księże Rektorze, Czcigodni Księża. Bardzo serdecznie dziękuję za przyjęcie które mnie spotkało. Co roku jestem tu mile przyjmowany. Nie mogę pozostawić bez odpowiedzi tych serdecznych słów, które tu przed chwilą padły z ust ks. rektora. Pracę państwową uważałem zawsze za największe szczęście. Nigdy nie była mnie ona za ciężką, nie tylko dlatego, że staje się ona racją bytu człowieka, ale i dlatego, że pozwala zbierać takie gratulacje jakie zebrałem dzisiaj. Będąc małym pionkiem grupy ludzi, którzy poświęcili czas i troski dla zwycięstwa, które nie jest tylko emanacją zgrupowanego społeczeństwa, które i Wy Księża reprezentujecie, cieszę się, że rzeczywiście rok ostatni był tak szczęśliwym. Odnieśliśmy zwycięstwo duże, które zawdzięczamy temu, że polityka zagraniczna Polski ani na krok po śmierci Marszałka nie zboczyła z drogi obranej przez Niego. My, którzyśmy mieli szczęście współpracować z Marszałkiem mieliśmy zawsze jedno pytanie. Czy na każdym kroku byłby Marszałek z nas zadowolony. Czy utrzymamy linię, która przez Niego została nakreśloną. W osobie ministra Becka zostawił Marszałek godnego kierownika. W ostatnich latach nie zboczyliśmy $\mathrm{z}$ drogi obranej i zebraliśmy plon. Przeżyliśmy wszyscy te wielkie momenty z wzruszeniem zasłużonej dumy, które nam przyniosła i wiosna i jesień. Ale zwycięstwo nawet najpiękniejsze pociąga za sobą i obowiązki. Polska rośnie i coraz więcej zdobywa w świecie szacunku, ale to nakłada na nas coraz to nowe obowiązki, które spełnić musimy, aby zwycięstwo było trwałe. $\mathrm{W}$ jednym $\mathrm{z}$ moich przemówień powiedziałem, że czeka nas nie łatwiejsza przyszłość. Rzeczywiście im się jest większym, tym przyszłość trudniejsza, choć siły są większe i zapał. Zdaje mi się, że w tych chwilach wzrok nasz musimy zwrócić na nowe zadania i obowiązki i zastanowić się nad tym, jak je spełnić. Spełnimy je o tyle, o ile zwiększymy nasze wysiłki ku zjednoczeniu.

Jesteśmy w kraju, w którym przykłady są pouczające, że brak tej jedności utrudnia pracę państwową. Musimy pamiętać, że znajdujemy się w takim położeniu geograficznym i politycznym, które wymaga zjednoczenia i w centrum chaosu świata powojennego, który $\mathrm{z}$ jednej strony na Wschodzie szuka rozwiązania $\mathrm{w}$ dziedzinie materializmu, $\mathrm{z}$ drugiej strony w poszukiwaniach zmierzających do pogaństwa. To są zagadnienia, którymi musi się dzisiaj zająć społeczeństwo. Jeżeli spojrzymy na nasze zadania w poszczególnych dziedzinach życia codziennego, wszędzie widzimy jedno. Musimy z siebie wykrzesać nowe siły, które zakreślą nowe drogi dla lepszej przyszłości. A jak je znajdziemy ? Tylko przez jedność, przez wspólny wysiłek, przez przesiąknięte miłością prawdziwą dążenie dla dobra Rzeczypospolitej. Jesteśmy tylko skrawkiem tego społeczeństwa, ale zadania nasze nie są różne, ale równie równe i dla nas na tym terenie również konkretne. Wspomniał ks. rektor o „Dzienniku Ludowym”. Jego likwidację musimy zanotować po stronie pozytywnej, jako coś co zapowiada łatwiejszą walkę, coś co powinno przyczynić się 
do zjednoczenia naszych wysiłków w jednym kierunku. Głębsza współpraca emigracji polskiej ma jednak dwie wspólne cechy, polskość i katolicyzm. Do czego powinniśmy dzisiaj wszyscy zmierzać. Do podniesienia emigracji polskiej i umocnienia jej na zasadach katolickich, do podniesienia zdrowego w niej momentu. Jestem głęboko przekonany, że podnosząc te zagadnienia, jestem zgodny z tym co się dzieje w Polsce, gdzie wysiłek ten przyczynił się do zwycięstwa $\mathrm{w}$ polityce zagranicznej i może być podstawą do dalszych poczynań. Jestem przekonany, iż w zgodzie w tym kierunku, jestem z tym gronem wobec którego z taką przyjemnością przemawiam. Ja bardzo cenię pracę księży. Stosunek mój do duchowieństwa jest zawsze szczery i takiż obserwuje z Waszej strony. Co mi największą sprawia radość, to fakt, że na emigracji pracujemy bez rozdźwięku i dlatego zapewniam, że duchowieństwo cieszy się i cieszyć będzie opieką z naszej strony leżącą w granicach i ramach naszych możliwości. Sądzę, że tak wyczerpałem temat mojego przemówienia, którego celem jest podziękowanie za tak serdeczne przyjęcie i złożenie w końcu życzeń: pełnego zjednoczenia emigracji dla utrzymania polskości i religii. To będzie życzenie, które będzie drogie i Wam i mnie, jako Przedstawicielowi Rzeczypospolitej. (oklaski)

Ks. rektor dziękując za przemówienie zaznacza, że my księża dążyliśmy i dążymy do skonsolidowania emigracji i nie ma przeszkód do dalszej pracy, jak bowiem mieliśmy sposobność słyszeć z ust P. Konsula Kawałkowskiego, władze konsularne doceniają ważność i potrzebę podkreślenia momentu religijno-katolickiego w naszej pracy organizacyjnej.

Po przemówieniach ks. Makulec kontynuuje swój referat bardzo ciekawy na temat zadań w pracy nad młodym pokoleniem na emigracji, której hasłem być winno w czasach dzisiejszych. Frontem do polskiego dziecka.

Ks. rektor serdecznie dziękuje za referat i zaznacza, że dziećmi w szczególniejszy sposób winniśmy się zająć, bo to drogocenne perly, które musimy wnieść do skarbnicy naszej Ojczyzny.

Ks. dr Mącior stawia wniosek, by ułatwić dzieciom we Francji zobaczenie Ojczyzny, by co roku bodaj cześć dzieci mogła w czasie wakacji spędzić szereg wolnych dni w kraju dla przyswojenia sobie znajomości polskiego języka.

W odpowiedzi na piękny projekt wnioskodawcy ks. rektor dziękując prosi Go, aby już w tym roku zechciał przyjąć na siebie obowiązek ulokowania na koloniach letnich pierwszej serii wycieczki dzieci, które w tym roku skierujemy do Polski. Wniosek przechodzi wśród akompaniamentu licznych oklasków.

Ks. Kwaśny prosi ks. Makulca o podanie kilku danych statystycznych z rozwoju organizacji dzieci.

Ks. Makulec odpowiadając komunikuje, że w Związku zapisanych jest 7230 dzieci, w tym 3200 chłopców i 4030 dziewczynek. Wspólnych Komunii św. było 452, liczba dzieci przyjmujących Komunię św. 40 000. Nabożeństw uroczystych 96, zebrań 804, zbiórek 1232, uroczystości 68, wycieczek 320, świetlic posiada Związek 32, sztandarów 38, bibliotek 39, odegrano 2300 teatrzyków, „Małego Polaka” wychodzi obecnie 2430 egzemplarzy. 
Następnie ks. [Czesław] Krzyszkowski ${ }^{32}$ omawia szeroko sprawę przygotowanego przez siebie nowego Katechizmu - Biblii, który już nie za długo się ukaże jako najtańsza książka na świecie, a tak przystępnie wydany, że nawet analfabeci z ilustracji w nim zawartych wiele skorzystać będą mogli.

$\mathrm{Na}$ zapytanie ks. [Wiktora] Miedzińskiego ${ }^{33}$, czy wspomniany katechizm ma być obowiązującym wszystkich, odpowiada ks. rektor iż na razie nie, gdyż nie zdał jeszcze swej próby ogniowej.

32 Czeslaw KrzYszKowsKi - kapłan diecezji sandomierskiej. Urodził się 2 maja 1898 w Skalbmierzu. Syn Andrzeja i Anny z d. Śliwińska. Szkołę powszechną i gimnazjum ukończył w Pińczowie. Od 1915 rozpoczął studia filozoficzno-teologiczne w Wyższym Seminarium Duchownym w Sandomierzu. Tamże, 5 września 1920 z rąk bpa M. Ryxa przyjął święcenia kapłańskie. Od 6 września 1920 pracował jako wikariusz w Staszowie, gdzie był jednocześnie prefektem gimnazjum prywatnego i szkół powszechnych. W 1922 uczęszczał na wykłady na Wydziale Prawa UJ w Krakowie, łącząc je z obowiązkami duszpasterskimi. Po otrzymaniu zezwolenia na studia stacjonarne (17 czerwca 1922) przeniósł się do Poznania. Tam po uzyskaniu świadectwa dojrzałości, podjął studia na Wydziale Nauk Społecznych i Wydziale Prawa (prawo i ekonomia). Aby zapewnić sobie źródło utrzymania od 1 sierpnia 1922 do 1 grudnia 1926 pracował jako prefekt, nauczyciel i dyrektor na kursach maturalnych Pedagogium Akademickiego w Poznaniu, w 1922 był wikariuszem przy kościele św. Jana w Poznaniu. We wrześniu 1924 pracował jako bibliotekarz terminowy w Instytucie Socjologii UP. 22 marca 1927 na Uniwersytecie Poznańskim uzyskał stopień magistra nauk ekonomiczno-politycznych. 9 lipca 1927 został prefektem Gimnazjum i szkół powszechnych w Kozienicach. Od lipca 1929 podjął posługę duszpasterską wśród wychodźstwa polskiego w Roubaix (Francja). 15 września 1930 podjął studia uniwersyteckie w Lille. Od 1 października 1931 został duszpasterzem w Longwy. 1 sierpnia 1936 był duszpasterzem w Neux les Mines, a od 1940 pełnił obowiązki duszpasterskie w Lyonie, Clermont - Ferand. We Francji wydał obszerny katechizm adresowany do Polonii, zalecany przez Polską Misję Katolicką oraz zwięzły Podręcznik religii rzymskokatolickiej (1939). Opublikował też popularną wśród Polonii książeczkę pt. Na chwałę Boża. W 1943 został aresztowany przez Niemców i osadzony w więzieniu w Montrambau. Od 24 maja 1944 przebywał w obozie koncentracyjnym Neuengamme k. Hamburga (nr obozowy 30720). Zmarł w obozie KL Neuengamme k. Hamburga 3 maja 1945. [Prawdopodobnie utonął na jednym ze statków zbombardowanych przez Aliantów, podczas ewakuacji obozu koncentracyjnego KL Neuengamme]. Archiwum Diecezjalne w Sandomierzu. Akta Kurii Diecezjalnej Sandomierskiej. Duszpasterstwo na emigracji. Zaczęte w roku 1917. Skończone w 1961; Archiwum Polskiej Misji Katolickiej we Francji. F. IV. Praca duszpasterska kapłanów Misji we Francji okupowanej przez Niemców pod kierownictwem ks. Cz. Wędziocha, [p.o.] Rektora Misji, w 1. 1940-1944/1945. F. IV. 1. Duszpasterze: 17. Krzyszkowski Czesław, 1944 w Hamburgu (6 VIII) jako Schutzhäftling; Materiały do dziejów Polskiej Misji Katolickiej we Francji, z. IV-II/II: Księża polscy w duszpasterstwie Pótnocnej Francji 1922-1929, oprac. O.B. Panek OC, Paris 1992, s. 99-100; bp F. JoP, Księża diecezji sandomierskiej zamęczeni podczas drugiej wojny światowej. 20. Ks. Czesław Krzyszkowski, „Kronika Diecezji Sandomierskiej” 4(1949), s. 158-160; ks. B. Stanaszek, ks. R. Nowakowski, Stownik biograficzny księży diecezji sandomierskiej XIX-XX w., t. II: H-t, Sandomierz 2015, s. 163-164.

33 WikTOR MiedzIŃSKI - kapłan archidiecezji poznańskiej. Urodził się 15 listopada 1910 w Borzęciczkach. 17 czerwca 1934 z rąk kard. A. Hlonda przyjął święcenia kapłańskie. Obowiązki duszpasterskie podjął 14 grudnia 1934 jako wikariusz w Margoninie. 15 grudnia 1935 w tym samym charakterze podjął obowiązki duszpasterskie w Kaszczorze. Od 12 maja 1937 rozpoczął posługę duszpasterską wśród wychodźstwa polskiego we Francji, obsługując kolonie polskie w: Algrange, Clouange, Dieuze, Grenoble, Hagodange, Hettange-Grande, La Saule, Metz, Montceau-Les-Mines, 
Ks. dziekanowi [Władysławowi] Mateuszkowi ${ }^{34}$ na pytanie o cenę katechizmu odpowiada autor, iż nie wyniesie więcej, jak 6 fr.

$\mathrm{Na}$ tym dyskusję na ten temat zakończono.

We wnioskach ks. dr Wędzioch proponuje zaprowadzenie „książki rodzinnej” w koloniach, w której notowano by zawsze daty ślubu kościelnego, chrztu itd.

Ks. Makulec stawia wnioski.

1) Wszystkie organizacje dziecięce nazwać stowarzyszeniami „Dzieci Polskich Rycerstwa Chrystusowego".

2) Święta Bożego Narodzenia obchodzić jak dzień dziecka.

3) Misja zamianuje poszczególnych dyrektorów Stow. Dzieci.

4) „Mały Polak” będzie oficjalnym organem Zw. Stow. Dzieci.

Wszystkie wnioski przyjęto.

Paris, Rombas, Saint-Privat, Ste-Marie-Aux-Chenes, Talange, Uckange. Od 1958 był proboszczem w parafii pw. NMP Wspomożycielki Wiernych w Szamocinie. W 1961 objął parafię w Krotoszynie. Zmarł 6 czerwca 1982. Pochowany został w Krotoszynie. Archiwum Polskiej Misji Katolickiej we Francji. P. II. „Kwestionariusz” osobowy, prezentujący stan z 20 stycznia 1949. 44. Miedziński Wiktor; P. V. Akta osobisto duszpasterskie księży pracujących w ośrodkach duszpasterskich PMK we Francji, gromadzone po 1945, 160. Miedziński Wiktor; P. VI. Ankieta personalna sporządzona w 1945 (-1955), 122. Miedziński Wiktor.

34 WeadysŁaw Mateuszek - kapłan diecezji władywostockiej. Urodził się 30 listopada 1899 w miejscowości Łyse k. Bielska Podlaskiego. Syn Franciszka i Kamilli z d. Iwanowska. Szkołę średnią - realno-techniczną ukończył w Nikołajewsku nad Amurem, i dalej kontynuował na Politechnice we Władywostoku. W 1. 1923-1928 podjął studia filozoficzno-teologiczne w Wyższym Seminarium Duchownym w Lublinie. Tamże, 24 czerwca 1928 z rąk ks. bpa Mariana Fulmana przyjął święcenia kapłańskie. W 1. 1928-1930 studiował na Uniwersytecie Misji Wschodnich w Rzymie. Od 1 lipca 1930 podjął posługę duszpasterską wśród wychodźstwa polskiego we Francji. Początkowo w Paryżu, od 1935 był duszpasterzem w Le Creusot, od 1937 w Les Gautherets. 6 czerwca 1948 zrezygnował z pracy duszpasterskiej i podjął nowicjat u księży marianów, skąd 8 grudnia 1948 przeniósł się do Chevilly i podjął nowicjat u księży pallotynów. Nowicjat opuścił 22 lutego 1949. Kolejną próbę podjął u Misjonarzy Matki Bożej z La Salette, gdzie 31 stycznia 1950 w Olivet rozpoczął nowicjat. Pierwszą profesję zakonną złożył 2 lutego $1951 \mathrm{w}$ Olivet, a 2 lutego 1954 tamże wieczystą. W 1. 1949-1952 był misjonarzem w Olivet, 1952-1954 misjonarzem w Cordobie, 1954-1955 misjonarzem w Milwaukee i Olivet, 1955-1956 wikariuszem w Beauséjour, 1956-1957 proboszczem w Elma, 1957-1963 misjonarzem w Elma, 1963-1970 kapelanem szpitala św. Józefa w Kenora, 1970-1972 misjonarzem w Thunder Bay, 1972-1975 misjonarzem w Milwaukee. Zmarł 10 lutego 1975 w Milwaukee. Pochowany został na cmentarzu w Twin Lakes. Archiwum Regi Miłosierdzia Bożego Księży Pallotynów w Paryżu, Notes mistrza nowicjatu ks. Misiaka Alojzego; Archiwum Polskiej Misji Katolickiej we Francji. P. Personalia. P. II. „Kwestionariusz” prezentujący stan z 20 stycznia 1949, 41. Mateuszek Władysław; P. IV. Ankieta personalna księży pracujących w ośrodkach duszpasterskich PMK w 1943: 22. Mateuszek Władysław, diec. Władywostok.; praca: Baudras 5 lat; Le Creusot 2 lata; Les Gautherets 6 lat, tu mieszkał; P. V. Akta osobisto duszpasterskie kapłanów gromadzone po 1945; P. V. 152. Mateuszek Władysław; P. VI. Ankieta personalna sporządzona w 1945, 116. Mateuszek Władysław; G. Garçon, Les catholiques polonais en France. Les années de foundation 1919-1949, Lille 2004, s. 177, 223, 227, 241, 259, 292, 294, 320. 
W wolnych głosach przemawia jeszcze ks. prof. Jakubisiak, który w serdecznych słowach ostrzegając konfratrów przed rutyną w czynnościach duszpasterskich i pewnego rodzaju zmechanizowaniem naszej pracy, radzi zwracać uwagę szczególną na brewiarz i mszał. Radzi stałe codzienne czytanie Pisma Świętego.

Serdecznie dziękując przedmówcy ks. rektor, a gdy w tym momencie wchodzi na salę Monseigneur Chaptal zostaje powitany bardzo serdecznie, odpowiadając również serdecznym na powitanie przemówieniem.

$\mathrm{W}$ wolnych głosach ks. [Franciszek] Wahrol ${ }^{35}$ wypowiada się za zorganizowaniem jednej wspólnej pielgrzymki do Lourdes. Termin pielgrzymki zostawiono Rektoratowi Misji do ustalenia.

W końcu programu porządku dziennego uchwalono wysłanie telegramów hołdowniczych do: Pana Prezydenta Rzeczypospolitej, do Jego Eminencji Ks. Kardynała Prymasa Polski, Marszałka Rydza-Śmigłego. Wysłanie telegramów przyjęto licznymi oklaskami.

Następnie ks. rektor odczytał rezolucje w liczbie 8, które również przyjęto oklaskami.

Po odczytaniu rezolucji zabiera głos ks. rektor. Dobiegamy - mówi - do końca naszego Zjazdu. Zjazd ten wykazał, że nasze zadania i obowiązki są bardzo wielkie, a obowiązki nasze spełniać zdołamy o tyle, o ile nasze szeregi będą mocno skonsolidowane, o ile nasze w nasze prace wniesiemy Ducha Bożego. Bóg dał światu kapłanów, niech więc kapłani dadzą światu Boga. Dziękuję raz jeszcze wszystkim za udział w Zjeździe a w szczególności Panu Ambasadorowi, Monseigneur'owi Chaptalowi i Czcigodnemu Gościowi z Ojczyzny ks. prałatowi Kaczyńskiemu. Szczerą wdzięczność wyrażam Sekretarzowi Zjazdu za protokołowanie obrad.

Wszystkim drogim Konfratrom życzę, by wzmocnieni na duchu po ćwiczeniach duchownych, podnosili coraz wyżej stan życia religijnego naszych rodaków. Oby nasza wspólna praca wydała jak najlepsze owoce ku chwale Boga, pożytkowi dusz polskich i ku chwale Ojczyzny.

Kończę i zamykam nasz Zjazd zwołany do Clamart na dzień 25 listopada 1938 r. Zjazd zakończono wspólnym odmówieniem „Te Deum”.

Niech będzie Pochwalony Jezus Chrystus.

Według stenogramu ks. dziekana A. Sawickiego.

[odręcznie] Za zgodność - Ks. F. Cegiełka

Paryż, dn. 31.XII.38.

Kier. Pol. Misji Kat. we Fr.

35 FranciszeK Wahrol (Warchoł) - kapłan Zgromadzenia Księży Misjonarzy św. Wincentego a Paulo CM (lazarysta). Urodził się 9 października 1897 w Borszczowie, pow. Przemyślany. Do zgromadzenia wstapił w 1916. Studia filozoficzne i teologiczne odbył na Kleparzu i na Stradomiu. Święcenia kapłańskie z rąk abpa S. Sapiehy przyjął 21 grudnia 1921 w Krakowie. Przez 8 lat był wikariuszem w Miletynie Nowym. Posługę duszpasterską we Francji podjął w lipcu 1930 w Lyonie. Od września 1931 w Saint-Etienne. We wrześniu 1939 został przeniesiony do Waziers (de Notre-Dame), Curbevoie, Saint-Rictrude. Zmarł w Gautherets, 31 sierpnia 1969. Archiwum Polskiej Misji Katolickiej we Francji. P. IV. Ankieta personalna księży pracujących w ośrodkach duszpasterskich PMK w 1943; [52 odpowiedzi]; 45. Wahrol Franciszek; Misjonarze św. Wincentego a Paulo w Polsce (1651-2001), t. II-1: Biografie, s. 289; W. UmiŃski, Polska prowincja Zgromadzenia Księży Misjonarzy, s. 292; Materiaty, z. II, s. 107-109. 


\section{BIBLIOGRAFIA}

\section{Źródła}

Archiwum Archidiecezjalne w Gnieźnie, Archiwum Prymasa Polski, Akta Protektora Wychodźstwa Polskiego, Francja - PMK Varia, Dział III, Vol IV/16, Przyszłość Misji pod względem duszpasterskim.

Archiwum Archidiecezjalne w Poznaniu, Akta Kurii Metropolitalnej w Poznaniu, Akta personalne, Krupiński Marian Aleksander, KA 9255.

Archiwum Archidiecezjalne w Przemyślu, Akta personalne księży. Teczka personalna: ks. Kwaśny Kazimierz.

Archiwum Diecezjalne w Sandomierzu. Akta Kurii Diecezjalnej Sandomierskiej. Duszpasterstwo na emigracji. Zaczęte w roku 1917. Skończone w 1961.

Archiwum Regi Miłosierdzia Bożego Księży Pallotynów w Paryżu, Notes mistrza nowicjatu ks. Misiaka Alojzego.

Archiwum Polskiej Misji Katolickiej we Francji.

E. IV. 15. 1. Stowarzyszenie Dzieci Polskich we Francji; projekty: księdza W. Rogaczewskiego 10. 05. 1932;

F. Duszpasterstwo - jego organizacja i życie religijne wiernych w polskojęzycznych ośrodkach duszpasterskich, 1926-1993.

F. IV. Praca duszpasterska kapłanów Misji we Francji okupowanej przez Niemców pod kierownictwem ks. Cz. Wędziocha, [p. o.] Rektora Misji, w 1. 1940-1944/1945.

F. IV. 1. Duszpasterze:

17. Krzyszkowski Czesław.

38. Szewczyk Antoni.

22. Makulec Ludwik.

F. VIII. 1. Duszpasterstwo „objazdowe”, 1927-1952; dok. z 27 XI 1933: Podział departamentów wśród duszpasterzy polskich, objeżdżających robotników, zwłaszcza rolnych (13 rejonów), Zakładka 1. 2: Korespondencja, zaangażowania i relacje z pracy duszpasterskiej w 1928, ks. rektora Szymbora i licznych polskich duszpasterzy: Rogaczewski;

F. VIII. 9. Objazdy kolonii polskich w latach 1927-1930, 1933-1934, 1940, 1955.

G. Duszpasterze Misji - kapelani.

G. VII. Wykazy ośrodków duszpasterskich, duszpasterzy, wspólnot zakonnych i statystyki PMK we Francji, 1929-1992.

G. VII. 1. Katalogi drukowane (schematyzmy) „Duszpasterstwa Polskiego we Francji” (oraz duchowieństwa): G. VII. 1. 1. Druki 1937/1938; 1939-1961: Duszpasterstwo Polskie we Francji (stan z dnia 15 stycznia 1939).

G. VII. 1. 1. Druki 1937/1938; 1939-1961: Duszpasterstwo Polskie we Francji (stan z dnia 1 marca 1940).

G. IX. 2. Odznaczeni (Czesław Wędzioch).

G. IX. 3. Wykaz niektórych odznaczonych Złotym Krzyżem Zasługi z Mieczami: ks. Wojciech Rogaczewski.

H. Historia duszpasterstwa polskiego we Francji. 
VII. Życiorysy i jubileusze rektorów Kościoła polskiego, Kościoła w Paryżu i PMK we Francji,

4. Cegiełka Franciszek.

5. Wędzioch Czesław.

J. Misje - ośrodki duszpasterskie.

I. Dekanat Paryski. 8. 3, Meaux 1929-1947.

II. Dekanat Pas de Caleis. 15. Salaumines 1929-1986.

III. Dekanat Nord. 7. Roubaix 1929-1991.

N. Zakony i zgromadzenia. IV. Stowarzyszenie Apostolstwa Katolickiego - Księża Pallotyni 1945-1996. 5. Duszpasterstwo polskie we Francji - zjazdy katolickie w Osny (informacje prasowe).

P. I. Personalia 1929-2000.

52. Nowak Stanisław (1937-1939).

P. II. „Kwestionariusz” osobowy, prezentujący stan z 20 stycznia 1949.

41. Mateuszek Władysław.

44. Miedziński Wiktor.

55. Plutowski Leon.

63. Sawicki Antoni.

82. Wędzioch Czesław SAC.

P. IV. Ankieta personalna księży pracujących w ośrodkach duszpasterskich PMK w 1943:

10. Jan Glapiak.

22. Mateuszek Władysław.

32. Plutowski Leon.

40. Szewczyk Antoni.

45. Wahrol Franciszek.

46. Wędzioch Czesław SAC.

223. Wojciech Rogaczewski.

229. Sawicki Antoni.

P. V. Akta osobisto duszpasterskie księży pracujących w ośrodkach duszpasterskich PMK we Francji, gromadzone po 1945.

26. Cegiełka Franciszek.

100. Kirschke Tadeusz.

145. Makiela Teodor.

146. Makulec Ludwik.

152. Mateuszek Władysław.

160. Miedziński Wiktor.

175. Myszko Franciszek.

180. Nowak Stanisław.

208. Plutowski Leon.

296. Wędzioch Czesław SAC.

P. VI. Ankieta personalna kleru polskiego pracującego we Francji.

17. Cegiełka Franciszek.

116. Mateuszek Władysław. 
122. Miedziński Wiktor.

161. Plutowski Leon.

222. Wędzioch Czesław SAC.

P. VII. Kwestionariusze osobowe ze zdjęciami [1959]

26. Sawicki Antoni.

P. VIII. Akta Osobowe 1927-2000.

19. Cegiełka Franciszek.

86. Makiela Teodor.

113. Wojciech Rogaczewski.

R. II. 7. Korespondencja Rektora i sekretarza w sprawach PMK, 1927-1939, R. II. 7. 1. Rok 1927, I -V.

W. Certyfikaty - Poszukiwania. I. Certyfikaty. I. 2. Lata 1947-1951. Wędzioch Czesław.

\section{Opracowania}

BADURA P.J., Jakubisiak Augustyn (1884-1945), w: Słownik polskich teologów katolickich 1918-1981, red. ks. L. Grzebień SJ, t. V, Warszawa: ATK 1983.

BADURA P. SJ, Unszlicht Julian (1883-?), w: Słownik polskich teologów katolickich 19181981, red. ks. L. Grzebień SJ, t. VII, Warszawa: ATK 1983.

Brudzisz M., Pierwsze zebranie księży Polskiej Misji Katolickiej we Francji, „Studia Polonijne" 33(2012).

DĄBSKa I., Jakubisiak Augustyn, w: Polski Słownik Biograficzny, t. X, Wrocław-Warszawa-Kraków 1962-1964.

DopieraŁa K., Kwaśny Kazimierz, w: Encyklopedia polskiej emigracji i Polonii, red. K. Dopierała, t. III: K-O, Toruń: Inne 2004.

Duszpasterstwo polskie w świecie. Informator, Paris 1970.

Dzwonkowski R. SAC, Cegiełka Franciszek Antoni, w: Encyklopedia polskiej emigracji i Polonii, red. K. Dopierała, t. I: A-E, Toruń: Inne 2003.

Dzwonkowski R. SAC, Polska opieka religijna we Francji 1909-1939, Poznań-Warszawa: Pallottinum 1988.

Dzwonkowski R. SAC, Przemiany polskiej parafii w północnej Francji (1922-1972). Studium historyczno-socjologiczne parafii w Oignies, „Studia Polonijne” 1(1976).

Dzwonkowski R. SAC, Wędzioch Czesław, w: Encyklopedia polskiej emigracji i Polonii, red. K. Dopierała, t. V: S-Ż, Toruń: Inne 2005.

GARÇON G., Les catholiques polonais en France. Les années de foundation 1919-1949, Lille: Facultélibre de Lettres 2004.

GomuŁczak F. SAC, Cegiełka. Pasterz Polonii, Ząbki: Apostolicum 2014.

Guzewicz W., ks., Duchowieństwo diecezji łomżyńskiej w II Rzeczypospolitej, Lublin: Wydawnictwo KUL 2003.

JANECZEK S., Jakubisiak Augustyn, filozof, teolog, duszpasterz, w: Encyklopedia Katolicka, t. VII, kol. 734-738.

Jemielity W., ks., Śp. Ks. Ludwik Makulec, „Rozporządzenia Urzędowe Łomżyńskiej Kurii Diecezjalnej" 4(1982). 
JoP F. Bp., Księża diecezji sandomierskiej zamęczeni podczas drugiej wojny światowej. 20. Ks. Czesław Krzyszkowski, „Kronika Diecezji Sandomierskiej” 4(1949).

JudYCKI A. et Z., Les Polonais en France. Dictionnaire biographique, vol. I, Paris: Editions Concordate 1996.

KAPUŚNIAK A., SZCZEPANIAK J., ks., Katalog alumnów krakowskiego seminarium duchownego (1901-1938), Kraków: Wydawnictwo Naukowe PAT 2006.

Materiały do dziejów Polskiej Misji Katolickiej we Francji, z. I: Księża polscy w duszpasterstwie okręgu paryskiego 1922-1929, oprac. O.B. Panek OC, Paris: Editions François-Dominique 1992.

Materiały do dziejów Polskiej Misji Katolickiej we Francji, z. IV-II/II: Księża polscy w duszpasterstwie Północnej Francji 1922-1929, oprac. O.B. Panek OC, Paris: Editions François-Dominique 1992.

Materiały do Dziejów Polskiej Misji Katolickiej we Francji, z. XVII: Księża polscy w duszpasterstwie na terenie Francji południowej 1940-1945, oprac. O.B. Panek OC, Paryż: Editions François-Dominique 1992.

MĄCIOR T., ks., Doroczny Zjazd Księży polskich we Francji, „Przegląd Katolicki” 4 XII 1938, s. 754-755.

M. l' abbe Julien Unszlicht, „La Semaine Religieuse du Dioces de Meaux” 84(1953).

Molin J.-B., L' abbe Julien Unszlicht, pretre du Dioces de Meaux (1883-1953), „Revue d'Histoire et d' Art de la Brie et du Pays de Meaux" 38(1987).

Mross H., ks., Słownik biograficzny kapłanów diecezji chełmińskiej wyświęconych w latach 1821-1920, Pelplin: Bernardinum 1995.

Myszor J., Leksykon duchowieństwa represjonowanego w PRL w latach 1945-1989, Górna Grupa: Wydawnictwo Księży Werbistów Verbinum 2003.

NiesŁony J., Słownik biograficzny Misjonarzy Oblatów Maryi Niepokalanej Prowincji Polskiej 1923-2016, Poznań: UAM 2016.

Olszar H., Polska opieka religijna we Francji w okresie międzywojennym i udział w niej księży diecezji katowickiej, „Wiadomości Archidiecezjalne. Organ Urzędowy Kurii Metropolitalnej w Katowicach” 3(1993).

Romejko A., ks., Duszpasterstwo polonijne w Wielkiej Brytanii, Tuchów: Mała Poligrafia Redemptorystów 2001.

SiomKaJŁo A., Kirschke Tadeusz, w: Encyklopedia polskiej emigracji i Polonii, red. K. Dopierała, t. II: F-K, Toruń: Inne 2003.

Smoroński K., Przedmowa, w: J. Unszlicht, Życie i nauka Jezusa Chrystusa w zarysie, Tuchów 1934.

Srebrne gody kapłańskie księdza dziekana Knapika, „Polska Wierna” 6 VII 1947.

Stanaszek B., ks., NowaKowski R., ks., Słownik biograficzny księży diecezji sandomierskiej XIX-XX w., t. II, H-Ł, Sandomierz: Wydawnictwo i Drukarnia Diecezji Sandomierskiej 2015.

SzYMaŃsKi J., ks., Duszpasterze Polonii i Polaków za granicą. Słownik biograficzny, t. I, Lublin: Miejska i Powiatowa Biblioteka Publiczna 2010.

SzYMaŃski J., ks., Duszpasterze Polonii i Polaków za granicą. Słownik biograficzny, t. II, Lublin: Miejska i Powiatowa Biblioteka Publiczna 2011. 
Śp. Ks. Czesław Wędzioch, „Duszpasterz Polski Zagranicą” 33(1982), z. 4(145), s. 607-609. Śp. Ks. inf. Kazimierz Kwaśny, „Duszpasterz Polski Zagranicą” 39(1988), z. 1, s. 152-155. Śp. Ks. infułat Władysław Staniszewski, „Duszpasterz Polski Zagranicą” 41(1990), z. 2(175), s. 347-351.

Śp. Ks. Jan Glapiak, „Duszpasterz Polski Zagranicą” 9(1958), z. 4(37), s. 449.

Tomkiewicz W., ks., Życie księdza Wojciecha Rogaczewskiego, w: 175-lecie Polskiej Misji

Katolickiej we Francji. Akta kolokwiów, t. I, red. G. Garçon i in., Nowy Sącz 2013.

TYLus S. SAC, Leksykon polskich pallotynów 1915-2012, Ząbki-Poznań: Apostolicum 2013.

TYLus S. SAC, Prace polskich Pallotynów wśród emigracji (do utworzenia francuskiej Regii Miłosierdzia Bożego - 2 VIII 1946), „Archiwa, Biblioteki i Muzea Kościelne” 66(1996). UmiŃsKi W. CM, Polska prowincja Zgromadzenia Księży Misjonarzy w latach 1918-1939, Kraków: Wydawnictwo IT Księży Misjonarzy 2009.

Unszlicht J., Duszpasterstwo Wychodźców w Francji, „Ateneum Kapłańskie” 35(1935). WeILER E., Die Geistlichen in Dachau sowie in anderen Konzentrationslagern und in Gefängnissen, Mödling: Missionsdruckerei St. Gabriel 1971.

Zjazdy i konferencje konsulów polskich we Francji. Protokoły i referaty 1931-1938, oprac.

H. Chałupczak, E. Kołodziej, Lublin 2009.

Zych S., Walicki B., Ksiądz Kazimierz Kwaśny, rektor Polskiej Misji Katolickiej we Francji (1900-1987). Przyczynek do biografii, „Przegląd Polsko-Polonijny” 2013, nr 5-6.

\section{OPIEKA DUSZPASTERSKA WŚRÓD POLAKÓW WE FRANCJI W ŚWIETLE PROTOKOŁU ZE ZJAZDU DUCHOWIEŃSTWA POLSKIEGO ODBYTEGO W CLAMART W 1938 ROKU}

\section{Streszczenie}

W okresie międzywojennym zarówno Kościół w Polsce, jak i władze rządowe zabiegały o zapewnienie rodzimej opieki religijnej wielomilionowej rzeszy wychodźstwa polskiego. Stwarzało to szeroką płaszczyznę współpracy. Motywacja miała różny charakter, od czysto pragmatycznej i politycznej na poziomie Ministerstwa Spraw Zagranicznych - ambasady, konsulatów, do religijno-humanitarnej na poziomie miejscowych duszpasterzy polskich, którzy na co dzień stykali się z rozproszoną i najbardziej opuszczoną pod względem opieki konsularnej i religijnej częścią emigracji.

Dla łatwiejszej administracji posługi duszpasterskiej rektor Polskiej Misji Katolickiej we Francji w 1923 roku w ramach rekolekcji kapłańskich rozpoczął duszpasterskie spotkania, „zjazdy duchowieństwa polskiego" - wszystkich kapłanów Misji, które służyły wymianie doświadczeń duszpasterskich i dyskusji nad pojawiającymi się problemami emigracji polskiej. Polska Misja Katolicka we Francji jurysdykcyjnie podlegała episkopatowi Francji, który ustanowił swojego delegata do duszpasterstwa migrantów.

W 1938 roku rekolekcje dla duszpasterzy polskich pracujących wśród wychodźstwa polskiego we Francji przeprowadził ks. Tomasz Mącior SAC. Odbywały się one w Clamart pod Paryżem. W ćwiczeniach tych uczestniczyło 50 duszpasterzy z ówczesnym rektorem PMK we Francji ks. F. Cegiełką. Po rekolekcjach tradycyjnie odbyły się obrady księży 
polskich, w których udział wzięli również: ambasador Polski Juliusz Łukasiewicz, konsul generalny w Paryżu Aleksander Kawałkowski, dyrektor Katolickiej Agencji Prasowej ks. Zygmunt Kaczyński i biskup sufragan Paryża Emanuel Anatol Chaptal.

Zakres podejmowanych wyzwań przez duszpasterzy polskich egzemplifikuje zamieszczony Protokół ze Zjazdu Duchowieństwa Polskiego odbytego po zakończeniu rekolekcji w Clamart pod Paryżem w dniu 25 listopada 1938 roku. Kopia dokumentu znajduje się w Archiwum Polskiej Misji Katolickiej we Francji, dokument oryginalny przechowywany jest w Archiwum Archidiecezjalnym w Gnieźnie.

Słowa kluczowe: Polacy we Francji; duszpasterstwo polskojęzyczne; duszpasterze polonijni

\author{
PASTORAL CARE AMONG POLES IN FRANCE \\ IN THE LIGHT OF THE PROTOCOL OF THE CONGRESS \\ OF THE POLISH CLERGY HELD IN CLAMART IN 1938
}

\title{
Sum mary
}

In the interwar period, both the Church and the Polish authorities sought to provide native religious care for a multi-million group of Poles in exile, which was a great area for cooperation. Their motivation was of a diverse nature: from purely pragmatic and political at the level of the Ministry of Foreign Affairs - embassies, consulates, to religious and humanitarian at the level of local Polish priests, who had to deal with a group of people scattered and abandoned in terms of consular and religious care.

For the easier administration of the pastoral ministry, the Rector of the Polish Catholic Mission in France, in 1923, as part of the priesthood retreat, began pastoral meetings, "congresses of the Polish clergy" - all priests of the Mission, aimed at the exchange of pastoral experiences and discussion of emerging problems related to Polish emigrants. The Polish Catholic Mission in France was under the jurisdiction of the episcopate of France, which appointed its delegate to the pastoral care of migrants.

In 1938, a retreat for Polish priests working for Poles in France was conducted by Fr. Tomasz Mącior SAC. It took place in Clamart near Paris. It was attended by 50 priests with the then rector of the Polish Catholic Mission in France, Fr. F. Cegiełka. After the retreat, the Polish priests' sessions were traditionally held, in which Polish ambassador Juliusz Łukasiewicz, consul general in Paris, Aleksander Kawałkowski, director of the Catholic Press Agency, Fr. Zygmunt Kaczyński and Paris suffragan bishop, Emanuel Anatol Chaptal participated.

The scope of the challenges undertaken by Polish priests is exemplified by the attached Protocol from the Polish Clergy Convention held after the retreat at Clamart on November 25, 1938. A copy of the document is stored in the Archives of the Polish Catholic Mission in France, and the original document is stored in the Archdiocesan Archives in Gniezno.

Key words: Poles in France; Polish language ministry; Polish priests 